\title{
Environmental risk factors for dementia: a systematic review
}

Lewis O. J. Killin ${ }^{1,2,3}$, John M. Starr ${ }^{1,2}$, Ivy J. Shiue ${ }^{1,4}$ and Tom C. Russ ${ }^{1,2,5,6^{*}}$

\begin{abstract}
Background: Dementia risk reduction is a major and growing public health priority. While certain modifiable risk factors for dementia have been identified, there remains a substantial proportion of unexplained risk. There is evidence that environmental risk factors may explain some of this risk. Thus, we present the first comprehensive systematic review of environmental risk factors for dementia.
\end{abstract}

Methods: We searched the PubMed and Web of Science databases from their inception to January 2016, bibliographies of review articles, and articles related to publically available environmental data. Articles were included if they examined the association between an environmental risk factor and dementia. Studies with another outcome (for example, cognition), a physiological measure of the exposure, case studies, animal studies, and studies of nutrition were excluded. Data were extracted from individual studies which were, in turn, appraised for methodological quality. The strength and consistency of the overall evidence for each risk factor identified was assessed.

Results: We screened 4784 studies and included 60 in the review. Risk factors were considered in six categories: air quality, toxic heavy metals, other metals, other trace elements, occupational-related exposures, and miscellaneous environmental factors. Few studies took a life course approach. There is at least moderate evidence implicating the following risk factors: air pollution; aluminium; silicon; selenium; pesticides; vitamin D deficiency; and electric and magnetic fields.

Conclusions: Studies varied widely in size and quality and therefore we must be circumspect in our conclusions. Nevertheless, this extensive review suggests that future research could focus on a short list of environmental risk factors for dementia. Furthermore, further robust, longitudinal studies with repeated measures of environmental exposures are required to confirm these associations.

Keywords: Dementia, Alzheimer's disease, Environment, Epidemiology, Risk factors

\section{Background}

Dementia is a syndrome of cognitive and functional decline, commonly occurring in later life as a result of neurodegenerative and cerebrovascular processes beginning earlier in the life course $[1,2]$. It is a major and growing public health concern with substantial increases projected in the future, particularly in low-to-middle income countries [3-5]. Furthermore, there is now a consensus that a substantial proportion of cases are potentially preventable [6-9]. Preventing or, perhaps more realistically, delaying

\footnotetext{
*Correspondence: T.C.Russ@ed.ac.uk

'Alzheimer Scotland Dementia Research Centre, University of Edinburgh, Edinburgh, UK

${ }^{2}$ Centre for Cognitive Ageing \& Cognitive Epidemiology, University of

Edinburgh, Edinburgh, UK

Full list of author information is available at the end of the article
}

the clinical onset of dementia would have a substantial effect on disease numbers [10-12]. It has been suggested that approximately a third of Alzheimer's dementia cases could be attributed to seven potentially modifiable risk factors: diabetes, midlife hypertension and obesity, smoking, depression, cognitive inactivity, and low educational attainment $[13,14]$. Adding to this amount of risk explained estimates of population attributable fractions derived from genetic factors [15], it is likely that a large proportion of variance in dementia risk remains unexplained. Therefore, there is an urgent need to identify further potentially modifiable risk factors for dementia.

There is evidence from studying geographical variation in dementia rates that environmental risk factors may also be important in the pathogenesis of dementia [16-19]. 
Two previous reviews have reported on environmental risk factors for Alzheimer's disease: both concluded that aluminium in drinking water and electromagnetic fields were important and one also highlighted occupational exposure to solvents and pesticides [20, 21]. However, both these reviews focused on Alzheimer's disease rather than all-cause dementia and neither of them used robust, systematic review methodology and so may not have covered all potentially important risk factors. Thus, we present the first comprehensive systematic review on environmental risk factors for dementia.

\section{Methods}

\section{Information sources}

We identified studies using three approaches. First, we conducted an electronic search of the PubMed and Web of Science databases from their start to January 2016 (Appendix 1). This search returned relevant primary studies and review articles. Second, we scrutinised bibliographies of included studies and review articles for additional studies which had not been identified by the search. Third, we reviewed a small number of hand-picked studies, based on our knowledge of the literature from scrutiny of articles related to publically available environmental data.

\section{Search strategy}

A shortlist of environmental factors was created based on previous work investigating environmental risk factors on health in general [22]. We also included factors not included in the general list which we knew had been linked to dementia risk, such as trace elements (for example, selenium [23]). Thus, the list of environmental factors which we searched for were air pollution, climate, ultraviolet radiation, green space, industrial pollution, water quality, noise pollution, low-frequency and radiofrequency radiation, radon, nuclear facilities, contamination, and trace elements.

\section{Screening \& eligibility}

Records returned from the search were screened based on titles and abstracts for suitability. Conference proceedings, books and editorial publications were excluded. Of the remaining studies, articles were then selected if they reported an association (including null associations) between an environmental factor and any dementia.

The main exclusion criteria were: animal studies; single case studies; studies where the exposure was a physiological measure which could not be directly linked with the environment, for example autopsy studies measuring levels of trace elements in the brain or measuring serum levels of a substance; studies with outcomes other than clinical dementia, e.g. cognitive decline; studies of specific symptoms or features (e.g. inflammation, oxidative stress) of dementia rather than the full dementia syndrome; studies where the exposure was solely nutritional; or where insufficient data were reported in the paper. Since we have recently published a systematic review and metaanalysis on the association between rurality and urbanicity on dementia [16], we did not consider this in the present review. Relevant review studies were carefully examined and additional primary articles not identified in the search were included (see below for definition). However, if a review reported multiple new studies, we included the review as a single source of evidence, summarising its findings rather than including every study individually (for example, Loef and Walach, 2012 [24] included 101 individual studies). We refer to the review studies in the main text and, where relevant, performed additional focused searches to identify any more recent articles which would have been included in these reviews. We also reported the most recent report from studies, removing any earlier report(s) (e.g., Rondeau et al., 2000 [25]).

\section{Quality of evidence}

Individual studies were appraised for quality. Large, prospective longitudinal studies with a robust measure of the risk factor in question at baseline and a clinical diagnosis of dementia were classified as being of quality level A. High quality cross-sectional studies (i.e., a large sample size with robust exposure and outcome measures) were considered level B quality, and studies which did not reach this level were considered level $C$ quality. The total evidence for an individual risk factor was synthesised to conclude whether there is strong, moderate, or weak evidence for an association (or lack of an association) between the risk factor and dementia or whether there is insufficient evidence to come to a conclusion. The criteria for each level of strength are given in Table 1. The reporting of this systematic review conforms to the PRIMSA guidelines [26].

\section{Results}

The PRISMA diagram for the process of screening and selecting records is shown in Fig. 1. From an initial total of 6665 studies returned from the searches, after removing duplicates across the environmental factors, 4784 studies were screened for suitability. Of these, 60 were identified as eligible for inclusion.

Table 2 shows the synthesised evidence from all studies with a global judgement about the strength of the evidence for an association from all published studies. The environmental risk factors under consideration fall into the following six groups: air quality, toxic heavy metals, other metals, other trace elements, occupational-related exposures, and miscellaneous environmental factors. Tables 3, 4, 5, 6, 7 and 8 summarise individual studies providing evidence for each risk factor in each category. The tables are organised alphabetically by exposure 
Table 1 Definitions of the strength of the reported association between individual risk factors and dementia

\author{
Strong evidence for environmental risk factor \\ There is a reported association with dementia in the majority of \\ published papers.
}

\section{Moderate or weak evidence for environmental risk factor}

Although the reported association with dementia is not seen in the majority of published papers, at least one published paper (or only one) supports the association.

Weak evidence may come from a single, poorly designed study.

\section{No evidence for environmental risk factor}

No association with dementia has been revealed either due to a lack of relevant research or the observed effect is not seen as significant.

with higher quality studies being reported first within this grouping and included review studies last of all.

\section{Air quality}

Studies of the association between environmental risk factors in air and dementia are summarised in Table 3. Higher levels of nitrogen oxides were observed to be associated with increased dementia risk in two prospective cohort studies: a 15 year prospective cohort study of 1806 healthy men and women in Umeå, Sweden, and a retrospective cohort study of almost thirty thousand individuals identified from the comprehensive Taiwanese health insurance database passively followed up for a decade [27, 28]. However, only the prospective study observed a dose-response pattern of association (adjusted HR per $10 \mu \mathrm{g} / \mathrm{m}^{3}$ increase in nitrogen oxides, $95 \%$ CI 1.05, 0.98, 1.12) [27]. This study grouped nitrogen oxides into the following cut-offs: 9,17 , and $26 \mu \mathrm{g} / \mathrm{m}^{3}$. The other study only observed an increased risk in the highest quartile and used the following cut-offs for $\mathrm{NO}_{2}$ concentration: 6652.3, 8349.0, and 9825.5 parts per billion [28]. The discrepancy in the pattern of observation observed in these two studies can be explained by the fact that the former explored higher levels of $\mathrm{NO}_{\mathrm{x}}-$ the highest cut-off from the latter study ( 10 parts per million) approximately corresponds to the lowest cut-off from the former study $\left(\sim 10 \mathrm{mg} / \mathrm{L} \equiv \mu \mathrm{g} / \mathrm{m}^{3}\right)$. The latter study also investigated carbon monoxide concentration and found a dose-response association with dementia risk for this exposure (adjusted HR compared to the lowest quartile, $95 \%$ CI: $1.07,0.92-1.25 ; 1.37,1.19-1.58 ; 1.61,1.39-1.85)$ [28]. Similar patterns were seen for men and women separately.

Environmental tobacco smoke was shown to be associated with dementia risk in a cross-sectional study of almost 6000 people in five provinces of China [29]. These investigators asked participants about exposure to environmental tobacco smoke at home, work, and in other locations, duration of exposure as well as estimating cumulative exposure. Rather than a clinical diagnosis, these investigators used the GMS-AGECAT algorithm which has been widely used in epidemiological studies, including the MRC Cognitive Function and Ageing Studies $[30,31]$. Higher levels of exposure were associated with an increased risk of severe dementia (O3-5) but not moderate dementia (O1-2). The cut off for moderate dementia used in this study showed only a positive predictive value of $68.6 \%$ but the cut off used for severe dementia performed much better (88.1\%) [32]. The cumulative dose analysis showed a dose-response association (adjusted HR compared to a cumulative dose of zero for groups $>0-24,25-49,50-74,75-99, \geq 100,95$ \% CI: 0.99, 0.76-

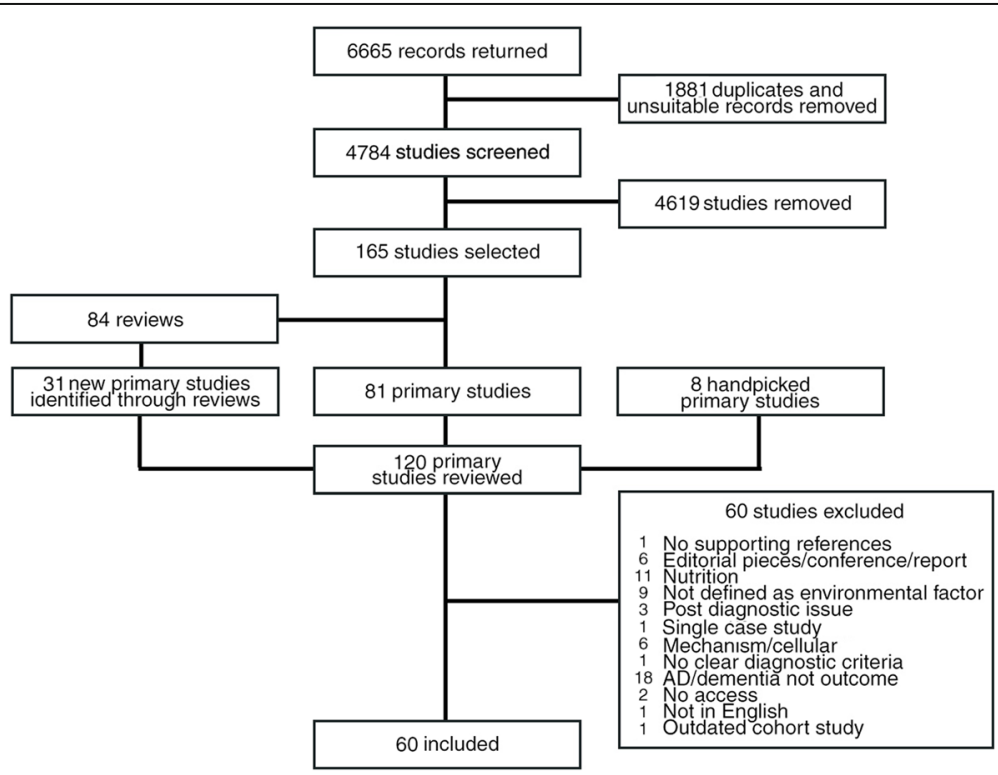

Fig. 1 PRISMA diagram showing the selection of studies from search to inclusion 
Table 2 Quality of overall evidence for each environmental factor

\begin{tabular}{|c|c|c|c|c|c|}
\hline \multirow[t]{2}{*}{ Factor } & \multicolumn{3}{|c|}{ N Studies $^{a}$} & \multirow{2}{*}{$\begin{array}{l}\text { Overall Strength } \\
\text { Of Evidence }\end{array}$} & \multirow{2}{*}{$\begin{array}{l}\text { Direction Of } \\
\text { Association }^{c}\end{array}$} \\
\hline & $\bar{C}$ & $x$ & $\overline{\mathrm{R}}$ & & \\
\hline \multicolumn{6}{|l|}{ Air } \\
\hline Nitrogen oxides $\left(\mathrm{NO}_{x}\right)$ & 2 & & & Strong & $\uparrow$ \\
\hline Carbon monoxide (CO) & 1 & & & Moderate & $\uparrow$ \\
\hline Environmental tobacco smoke & & 1 & & Moderate & $\uparrow$ \\
\hline Particulate matter $\left(\mathrm{PM}_{10} \&_{2.5}\right)$ & 1 & 1 & & Strong & $\uparrow$ \\
\hline Ozone $\left(\mathrm{O}_{3}\right)$ & 1 & 1 & & Strong & $\uparrow$ \\
\hline \multicolumn{6}{|l|}{ Toxic heavy metals } \\
\hline Arsenic & & 2 & & Moderate & $\uparrow$ \\
\hline Lead & & 1 & & Weak & $\uparrow$ \\
\hline \multicolumn{6}{|l|}{ Other metals } \\
\hline Aluminium & 1 & 15 & & Moderate & $\uparrow$ \\
\hline Calcium & 1 & & & Weak & - \\
\hline Cobalt & & 1 & & Weak & - \\
\hline Copper & & 2 & 1 & Weak & $\uparrow$ \\
\hline Iron & & 2 & 1 & Weak & $\uparrow$ \\
\hline Manganese & & 1 & & Weak & $\uparrow$ \\
\hline Molybdenum & & 1 & & Weak & - \\
\hline Nickel & & 1 & & Weak & - \\
\hline Uranium & & 1 & & Weak & - \\
\hline Zinc & & 2 & & Weak & $\uparrow$ \\
\hline \multicolumn{6}{|l|}{ Other trace elements } \\
\hline Fluoride & & 1 & & Weak & $\uparrow$ \\
\hline Selenium & & & 1 & Moderate & $\uparrow$ \\
\hline Silicon (and silica) & 2 & 2 & & Strong & $\uparrow$ \\
\hline \multicolumn{6}{|l|}{ Occupational } \\
\hline $\begin{array}{l}\text { Aluminium } \\
\text { (occupational exposure) }\end{array}$ & 1 & 3 & & Weak & $\uparrow$ \\
\hline Defoliants/fumigants & 1 & & & Weak & $\uparrow$ \\
\hline Diesel motor exhaust & 1 & & & Moderate & - \\
\hline Electromagnetic fields & 1 & & & Moderate & $\uparrow$ \\
\hline Excessive noise & 1 & & & Weak & $\downarrow$ \\
\hline Glues/adhesives & 1 & 1 & & Weak & $\uparrow$ \\
\hline Pesticides/fertilizers/herbicides/insecticides & 5 & 2 & 2 & Strong & $\uparrow$ \\
\hline Lead (occupational exposure) & & & 1 & Weak & - \\
\hline Metals (occupational exposure) & 1 & & & Moderate & $\uparrow$ \\
\hline Inks/dyes & 1 & & & Weak & - \\
\hline Paints/stains/varnishes & 1 & & & Weak & - \\
\hline Gasoline/fuels/oils & 1 & & & Weak & - \\
\hline Solvents/degreasers & 2 & 1 & 1 & Strong & $\uparrow$ \\
\hline Liquid plastics/rubbers & 1 & & & Weak & - \\
\hline Vibratory tools & 1 & & & Weak & - \\
\hline Radiation & 1 & & & Weak & $\uparrow$ \\
\hline
\end{tabular}


Table 2 Quality of overall evidence for each environmental factor (Continued)

Miscellaneous
Climate
Electric and magnetic fields
Mobile phone use
substantial effect on dementia risk

$1.28 ; 1.15,0.93-1.42 ; 1.18,0.87-1.59 ; 1.39,1.03-1.84$; $1.95,1.34-2.83)$. Also, all effect sizes were larger in never smokers than when ex-smokers were included.

A prospective Taiwanese study following almost a million people over ten years found an association between baseline ozone but not particulate matter up to $2.5 \mu \mathrm{m}$ in diameter $\left(\mathbf{P M}_{\mathbf{2 . 5}}\right)$ and incident Alzheimer's dementia [33]. However, change in exposure to both pollutants during follow up was associated with a two-to-three-fold increased risk of incident AD. A final cross-sectional study of 871 people in Taiwan also examined both particulate matter $\left(\mathbf{P M}_{\mathbf{1 0}}\right)$ and ozone concentration at the participant's home address, finding increased Alzheimer's dementia risk in the second and third tertiles of $\mathrm{PM}_{10}$ concentrations (adjusted OR, 95 \% CI: 1.68, 0.94$\left.3.00 ; 4.17,2.31-7.54 ; \mathrm{P}_{\text {trend }}<0.001\right)$ but only in the highest tertile of ozone concentrations (0.60, 0.33-1.09; 2.00, 1.14-3.50; $\mathrm{P}_{\text {trend }}=0.03$ ) [34]. They found similar patterns of association with vascular dementia.

Thus, the evidence for airborne environmental risk factors for dementia is consistent in the direction of association for all exposures and the overall strength of evidence, while based on relatively few studies, is moderate to strong.

\section{Toxic heavy metals}

Table 4 summarises the studies linking toxic heavy metals to dementia risk. There were two studies of arsenic, one of which was of grade-B quality and found no association with dementia; the grade- $C$ study found increased rates of dementia in areas with higher soil arsenic levels but this country-level simulation is less informative about risk factors in individuals $[35,36]$. A case-control study with 129 people in each group found that an excess of people with Alzheimer's dementia were born in areas with higher than average lead concentrations [37].

Overall, there was relatively little extant evidence for an association between toxic heavy metals and dementia risk.

\section{Other metals}

Table 5 summarises the studies focused on other metals and dementia risk. Aluminium was the most studied metal, with sixteen studies investigating its relationship with dementia including almost 22,000 people with dementia. The only high quality study - a prospective cohort study of almost four thousand older adults in south-west France (the PAQUID study [38]) - found that levels of aluminium consumption in drinking water in excess of $0.1 \mathrm{mg}$ per day were associated with a doubling of dementia risk and a three-fold increase in the risk of Alzheimer's dementia [39]. Of the remaining thirteen moderate quality studies, six found an association between increased aluminium levels in drinking water and increased dementia risk [40-45], four found no association [37, 46-48], and one found a protective effect of higher soil levels of aluminium [49]. In general, the larger studies showed a positive association and the smaller studies showed a null effect.

A prospective cohort study compared calcium levels in tap water with risk of developing Alzheimer's dementia. However, it is unclear if their not mentioning calcium as a predictor means that they failed to examine it or if it did not emerge from the models as an independent predictor. A cross-sectional study found no association between cobalt and dementia risk $[37,50]$. Two case-control studies and one review article summarising 101 studies considered copper and iron in relation to dementia [24, 37, 49]. The findings regarding copper were inconclusive. However, they reported that higher soil levels of iron were associated with an increased risk of dementia [37, 49]. The review article was inconclusive [24].

An excess of people with Alzheimer's dementia were born in areas with higher than average levels of manganese in a cross-sectional study [37]. The same study found no evidence for an association between molybdenum, nickel, uranium, or zinc with dementia risk [37]. However, another study found that higher zinc levels in the soil was associated with an increased risk of Alzheimer's dementia [49].

It is challenging to synthesise the published reports on the association between metals and dementia, and the published evidence for an individual element is often weak and/or contradictory. However, there is at least some evidence that calcium, cobalt, molybdenum, nickel, and 
Table 3 Individual studies reporting the association between environmental risk factors in air and dementia

\begin{tabular}{|c|c|c|c|c|c|c|}
\hline Study & Exposure & Sample description & $N$ & Methodology/design & Finding & Grade \\
\hline $\begin{array}{l}\text { Chang et al., } \\
2014 \text { [28] }\end{array}$ & $\mathrm{CO}$ and $\mathrm{NO}_{2}$ & $\begin{array}{l}\text { Comprehensive National } \\
\text { Health Insurance database } \\
\text { in Taiwan - people aged } \\
\geq 50 \text { years. }\end{array}$ & $\begin{array}{l}29537\left(\mathrm{NO}_{2} 29547\right) \text { men and } \\
\text { women of whom } 1718 \text { (1720) } \\
\text { developed dementia }\end{array}$ & $\begin{array}{l}\text { Retrospective cohort study: Cox PH } \\
\text { models. } \\
\text { Yearly average CO concentrations based } \\
\text { on location of clinic attended. Dementia } \\
\text { diagnoses were extracted from electronic } \\
\text { health records. }\end{array}$ & $\begin{array}{l}\text { Highest vs lowest quartile of } \mathrm{CO} \text { and } \\
\mathrm{NO}_{2} \text { was associated with an increased } \\
\text { risk of dementia incidence (multivariable } \\
\text { adjusted } \mathrm{HR}, 95 \% \mathrm{Cl}: 1.54,1.34-1.77 ; 1.61 \text {, } \\
\text { 1.39-1.85). Similar effects in men and } \\
\text { women. }\end{array}$ & A \\
\hline $\begin{array}{l}\text { Oudin et al., } \\
2015 \text { [27] }\end{array}$ & $\begin{array}{l}\text { Traffic-related air } \\
\text { pollution }\left(\mathrm{NO}_{x}\right)\end{array}$ & $\begin{array}{l}\text { Participants from the } \\
\text { Betula study, randomly } \\
\text { sampled from the general } \\
\text { population residing in the } \\
\text { Umeå municipality }\end{array}$ & $\begin{array}{l}\text { 1,806 healthy men and women } \\
\text { of whom } 302 \text { developed } \\
\text { dementia }\end{array}$ & $\begin{array}{l}\text { Prospective cohort study: Cox PH models. } \\
\text { Mean nitrogen oxide levels based on } \\
\text { baseline residence and dementia outcome } \\
\text { after } 15 \text { years. }\end{array}$ & $\begin{array}{l}\text { Highest:lowest quartile of } \mathrm{NO}_{x} \text { revealed } \\
\text { an increased risk of incident dementia } \\
\text { (adjusted } \mathrm{HR}, 95 \% \mathrm{Cl} 1.60,1.02-2.10 \text { ). } \\
\text { Similar results were observed in } \mathrm{AD} \\
\text { and VaD. }\end{array}$ & A \\
\hline $\begin{array}{l}\text { Chen et al., } \\
2013 \text { [29] }\end{array}$ & $\begin{array}{l}\text { Environmental } \\
\text { Tobacco Smoke }\end{array}$ & $\begin{array}{l}\text { Community dwelling adults } \\
\text { aged } \geq 50 \text { years living in rural } \\
\text { or urban areas of five } \\
\text { provinces of China. }\end{array}$ & $\begin{array}{l}5921 \text { men and women of } \\
\text { whom } 626 \text { had severe }(\mathrm{O} 3-5) \\
\text { and } 869 \text { moderate }(\mathrm{O} 1-2) \\
\text { dementia }\end{array}$ & $\begin{array}{l}\text { Cross-sectional study. Smoking status and } \\
\text { ETS exposure (at home, work, and other } \\
\text { places) defined by self-report. Dementia } \\
\text { was diagnosed using the GMS-AGECAT } \\
\text { algorithm. }\end{array}$ & $\begin{array}{l}\text { Multivariable-adjusted RR ( } 95 \% \text { Cl) for } \\
\text { exposure to ETS } 0.96(0.84,1.09) \text { for } \\
\text { moderate dementia and } 1.29(1.05 \text {, } \\
1.59) \text { for severe dementia. Risk of } \\
\text { severe dementia increased with } \\
\text { increasing duration and cumulative } \\
\text { dose, particularly in never smokers. }\end{array}$ & B \\
\hline $\begin{array}{l}\text { Jung et al. } \\
2015 \text { [33] }\end{array}$ & $\mathrm{PM}_{2.5}$ and $\mathrm{O}_{3}$ & $\begin{array}{l}\text { Individuals from Taiwan } \\
\text { entered into the longitudinal } \\
\text { health insurance database } 2000 \\
\text { (LHID2000) aged } \geq 65 \text { in } 2001 \text {. }\end{array}$ & $\begin{array}{l}95,690 \text { men and women of } \\
\text { whom } 1399 \text { developed AD. }\end{array}$ & $\begin{array}{l}\text { Prospective cohort study: Cox PH models. } \\
\mathrm{PM}_{2.5} \text { and } \mathrm{O}_{3} \text { levels recorded at } 70 \text { Taiwan } \\
\text { Environmental Protection Agency } \\
\text { monitoring stations from } 2000 \text { to } 2010 \text {. } \\
\text { These data were controlled for secondary } \\
\text { pollutants }\left(\mathrm{CO}, \mathrm{NO}_{2} \text { and } \mathrm{SO}_{2}\right) \text {. } \mathrm{AD} \text { was } \\
\text { identified when this was recorded at least } \\
\text { twice on the insurance database, based on } \\
\text { a physician diagnosis. }\end{array}$ & $\begin{array}{l}\text { Baseline } \mathrm{O}_{3} \text { was associated with an } \\
\text { increased risk of incident } \mathrm{AD} \\
\text { (multivariable-adjusted } \mathrm{HR} \text { per } \\
\text { interquartile range, } 95 \% \mathrm{Cl}: 1.06 \text {, } \\
1.00-1.12 \text { ) but baseline } \mathrm{PM} 2.5 \text { was } \\
\text { not (1.03, } 0.95-1.11 \text { ). Change in both } \\
\mathrm{O}_{3} \text { and } \mathrm{PM}_{2.5} \text { was associated with } \\
\text { increased } \mathrm{AD} \text { risk }(3.12,2.92-3.33 ; 2.38 \text {, } \\
2.21-2.56) \text {. This remained after } \\
\text { additionally adjusting for secondary } \\
\text { pollutants. }\end{array}$ & A \\
\hline $\begin{array}{l}\text { Wu et al., } \\
2015 \text { [34] }\end{array}$ & $\mathrm{PM}_{10}$ and $\mathrm{O}_{3}$ & $\begin{array}{l}249 \text { AD patients, } 125 \mathrm{VaD} \\
\text { patients (clinically diagnosed from } \\
\text { hospital clinics) and } 497 \text { controls } \\
\text { (from the elderly health check-up } \\
\text { program), all } \geq 60 \text { years in Taiwan. }\end{array}$ & 374 cases; 497 controls & $\begin{array}{l}\text { Cross-sectional study (case-control): } \\
\text { multiple regression. } 12 \text {-year } \mathrm{PM}_{10} \text { and } \\
14 \text {-year ozone exposure were estimated } \\
\text { from spatiotemporal models based on } \\
\text { residential location. }\end{array}$ & $\begin{array}{l}\text { Highest vs lowest tertile of } \mathrm{PM}_{10} \text { and } \\
\text { ozone exposure was associated with } \\
\text { increased } \mathrm{AD} \text { risk (adjusted OR, } \\
95 \% \mathrm{Cl} \text { : } 4.17,2.31-7.54 ; 2.00,1.14-3.50 \text { ). } \\
\text { Similar results were found for VaD. }\end{array}$ & B \\
\hline
\end{tabular}

$A D=$ Alzheimer's dementia, CO carbon monoxide, ETS environmental tobacco smoke, GMS-AGECAT the Automated Geriatric Examination for Computer Assisted Taxonomy algorithm used with the Geriatric Mental State interview $(\mathrm{O}=$ "organic" diagnosis from the AGECAT algorithm, levels $1-5), H R$ hazard ratio, $N O_{2}$ nitrogen dioxide, $O_{3}$ ozone, $O R$ odds ratio, $P H$ proportional hazards, $P M_{x}$ particulate matter up to $x$ micrometres in size, $\mathrm{VaD}$ vascular dementia 
Table 4 Individual studies reporting the association between toxic heavy metals and dementia

\begin{tabular}{|c|c|c|c|c|c|c|}
\hline Study & Exposure & Sample description & $N$ & Methodology/design & Finding & Grade \\
\hline Fox, 2014 [35] & Arsenic & $\begin{array}{l}\text { Spring Valley Community, } \\
\text { Washington, District of } \\
\text { Columbia. Spring Valley } \\
\text { was built on a chemical } \\
\text { weapons lab which caused } \\
\text { arsenic to be distributed to } \\
\text { the surface soil. }\end{array}$ & $\begin{array}{l}\text { Population of Spring Valley } \\
2006 \text { - 2010: } 24,762\end{array}$ & $\begin{array}{l}\text { Comparison of annual average } \\
\text { age-adjusted mortality rates } \\
\text { (per 100,000) between Spring } \\
\text { Valley, Chevy Chase (2004 - } \\
2010 \text { ) and the US (2007). } \\
\text { No measure of arsenic } \\
\text { concentration is given for } \\
\text { these areas at these times. }\end{array}$ & $\begin{array}{l}\text { AD mortality rate in Spring Valley } \\
\text { (22.8; Cl } 20.3-25.4) \text { was comparable } \\
\text { to the Chevy Chase (22; CI } 19-25) \\
\text { and US (24.70) rates. No statistically } \\
\text { significant difference. }\end{array}$ & B \\
\hline Dani, 2010 [36] & Arsenic & $\begin{array}{l}\text { Secondary analysis of } \\
\text { country-level data. }\end{array}$ & Country-level data. & Simulation. & $\begin{array}{l}\text { Slight increases in arsenic } \\
\text { concentration in soil were related to } \\
\text { exponential increases in dementia } \\
\text { rates at a country level. }\end{array}$ & $C$ \\
\hline Emard et al., 1994 [37] & Lead & $\begin{array}{l}\text { The IMAGE Project } \\
\text { covering the population of } \\
\text { Saguenay-Lac-Saint-Jean } \\
\text { (SLSJ), Québec. }\end{array}$ & $\begin{array}{l}129 \text { individuals with AD (clinically } \\
\text { diagnosed by standard medical } \\
\text { services) who were born in SLSJ. }\end{array}$ & $\begin{array}{l}\text { Cross-sectional study: principal } \\
\text { components analysis. Samples } \\
\text { of aquatic sediment were } \\
\text { analysed for geochemical } \\
\text { variables. AD cases were } \\
\text { identified from a registry. }\end{array}$ & $\begin{array}{l}15 \text { individuals with } A D \text { were born in } \\
\text { areas with lower than average } \\
\text { concentration of lead; } 49 \text { were born } \\
\text { in areas with higher than average } \\
\text { concentrations. This difference was } \\
\text { statistically significant }(P<0.05) \text {. }\end{array}$ & B \\
\hline
\end{tabular}

AD Alzheimer's dementia, $\mathrm{Cl}$ confidence interval, SD standard deviation, SEM standard error of the mean 
Table 5 Individual studies reporting the association between other metals and dementia

\begin{tabular}{llll}
\hline Study & Exposure & Sample description & $N$ \\
\hline $\begin{array}{l}\text { Rondeau et al., } \\
2009 \text { [39] }\end{array}$ & Aluminium & $\begin{array}{l}\text { PAQUID: A community-based co- } \\
\text { hort of 3,777 elderly people aged } \\
265 \text { years in SW France. }\end{array}$ & $\begin{array}{l}1925 \text { individuals of whom } 461 \\
\text { developed clinically diagnosed } \\
\text { dementia (364 AD). }\end{array}$ \\
Flaten, 1990 [40] & Aluminium & $\begin{array}{l}\text { The Norwegian population - } \\
\text { mortality data provided by the } \\
\text { Central Bureau of Statistics of } \\
\text { Norway. }\end{array}$ & $\begin{array}{l}\text { 5,642 male and 9,085 female } \\
\text { dementia deaths were recorded } \\
\text { 1974-1983. The denominator } \\
\text { population is estimated at 40.6 } \\
\text { million person-years. The population } \\
\text { of Norway was approximately 4 } \\
\text { million people during this period. }\end{array}$ \\
& &
\end{tabular}

Methodology/design

Finding

Prospective cohort study: $\mathrm{Cox}$ PH Highest.lowest quartile of aluminium A

Prospective cohort study: $\mathrm{COX} \mathrm{PH}$
models. Mean levels of aluminium in in drinking water was associated drinking water over the previous with an increased risk of dementia decade based on current residential and AD (multivariable-adjusted HR, location was linked to incident dementia over 15 years follow up. $95 \%$ Cl: $2.34,1.03-5.32 ; 3.04,1.32-$ Cross-sectional study: Pearson's correlation and relative risk. Four water samples (one per season) were collected in 1982-3 from 384 waterworks and analysed. Small municipalities were aggregated to regions of at least 10,000 inhabitants. regions of at least 10,000 inhabitant
Dementia was ascertained from death certification (any mention).

There was a correlation between the $\mathrm{B}$ aluminium content of drinking water at municipality level and dementia death rates in four time periods from 1969-83 in men and women $(P<0.025$ and $<0.005)$ but not with PD or ALS death rates. This pattern was less clear at county level.

Highest:lowest tertile of aluminium concentration was associated with an increased risk of dementia death in men and women (RR, $95 \% \mathrm{Cl}$ : $1.32,1.20-1.46 ; 1.42,1.32-1.54)$.

Forbes et al., 1995 [41] Aluminium Males from the Ontario Longitudinal Study of A between 1984 and 1991.

3161 patients with $A D$ or youngonset dementia.

Total sample not stated.

Cross-sectional study: Poisson regression. Water quality was based on 30 years' residential history. Dementia was identified from death certificates (underlying cause).

Highest:lowest tertile of aluminium concentration was associated with an increased risk of $A D$ and $A D$ plus young-onset dementia (RR, 95 \% Cl: $2.42,1.42-4.11 ; 1.96,1.15-3.32)$. Effect sizes were greater in analyses restricted to individuals aged $\geq 75$ years.

Some models showed a lower risk of dementia in the middle tertile of aluminium concentrations compared to the lowest.

Neri \& Hewitt, 1991 Aluminium Patients discharged from general [44] hospitals in Ontario, Canada in 1986.

2344 people aged $\geq 55$ years with a diagnosis of $\mathrm{AD}$ or young-onset dementia recorded and 2232 people matched for age and sex, with non-psychiatric diagnosis recorded.

Cross-sectional study (case-control) Aluminium concentration in drinking water based on residential location was compared with dementia diagnoses based on hospital discharge statistics.

1462 women from one centre of whom 60 developed clinically diagnosed AD. 323 had normal cognitive function and the remainder were lost to follow up. study cohort of women aged $\geq 75$ years.

\section{Prospective cohort study: logistic} egression. Water consumption consumption was included in follow up) was combined with local found to be a predictor of dementia tap water composition data. Demen- or if it wasn't included. tia was clinically diagnosed.

Cross-sectional study (case-control): There were no associations identified B logistic regression. Average levels of between aluminium concentrations

aluminium in drinking water based over three time periods (from age
Participants were selected from CT A total of 872 men (106 AD, 99 centres in the UK. other dementia, 226 brain cancer,
The authors report a dose-response pattern of association (OR for quartiles 2-4 compared to lowest, $2.59 ; 1.46,0.71-2.95$ ) but a 1 , 0.61 reported but calculated from data reported in paper) include unity. 
Table 5 Individual studies reporting the association between other metals and dementia (Continued)

Table 5 Individual studies reporting the association between other metals and dementia (Continued)

McLachlan et al., 1996 Aluminium [43]

Frecker, $1991[42]$ Aluminium Newfoundland, 1985-86

Participants were selected from brain tissue bank in Ontario, Canada.

Emard et al., 1994 [37] Aluminium

The IMAGE Project covering the population of Saguenay-Lac-SaintJean (SLSJ), Québec.

Patients were drawn from a specialist service in the north of England. Controls were randomly selected from the general

population.

Taylor et al., 1995 [48] Aluminium Same cohort as Forster et al, 1995 [47]

Water samples were obtained for 214 addresses of the 218 cases and
441 ther disease of the nervous system) deaths in 1986

129 individuals with AD (clinically diagnosed by standard medical services) who were born in SLSJ.

\section{on residential history (after age 25 years) was related to diagnosis based on hospital records.}

296 participants had AD, 89 had mixed dementia, 125 had no histopathological abnormalities, and 170 had other conditions (HD, schizophrenia, MS, multiple infarcts, diseases).

109 people with clinically diagnosed young-onset AD and 109 age- and sex-matched controls.

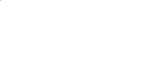
Average aluminium concentration diagnosed). of all individuals dying with associated with drinking water samples at those locations from 1986.

Cross-sectional study: principal components analysis. Samples of geochemical variables. AD cases were identified from a registry. were determined according to residential history (longest residence in the preceding 10 years plus controls.

\section{Cross-sectional study (case-control).} $\begin{array}{ll}\text { in domestic water supply of } & \text { associated with an increased risk of } \\ \text { residential location at death (10 year } & A D \text { and dementia (OR, } 95 \% \mathrm{Cl}: 1.7 \text {, }\end{array}$ residential history was available for a subsample) were compared to
dementia status (neuropathologically Effect sizes were larger for the

Cross-sectional study. Place of birth dementia was identified and aquatic sediment were analysed for

Cross-sectional study (case-control) Aluminium levels in drinking water birthplace for a subset of 80 cases and controls) at local authority district level.

Cross-sectional study (case-control). Aluminium concentration in water samples drawn from the place of residence at which they had lived longest within 10 years prior to onset of dementia (or equivalent date for controls).

25 years to diagnosis; from age 25 years to 10 years before diagnosis; and the ten years preceding diagnosis) with each of the three comparison groups.

Aluminium concentration $>100 \mu \mathrm{g} / \mathrm{L}$ compared to $<100 \mu \mathrm{g} / \mathrm{L}$ was associated with an increased risk of $1.2-2.6 ; 1.7,1.2-2.5)$.

Effect sizes were larger for the subgroup analysis based on 10-yea residential history (2.6, 1.2-5.7; 2.5, 1.2-5.3).

The area with the highest dementia mortality (37.5\% in 1985 and $68.8 \%$ in 1986) also had the highest aluminium concentrations in drinking water. This association was not assessed for statistical significance, but was argued to not significance, but was argued to not
be confounded by age, sex or place be confounded by age, sex
of residence stated on death certificate.

44 individuals with $A D$ were born in $B$ areas with lower than average concentration of aluminium; 41 were born in areas with higher than average concentrations. This difference is not statistically significant.

There was no evidence of an association between aluminium concentration in drinking water and dementia risk (e.g. aluminium $>149$ mg/L OR, $95 \%$ Cl: recent residence 1.0, 0.41-2.43; birthplace 1.1, 0.38-3.35).

There were no differences in

aluminium concentrations in samples for cases or controls $(P=$ 0.60)

Cross-sectional study (case-control). Of all variables involved in the Aluminium concentration in drinking speciation of aluminium in drinking 
Table 5 Individual studies reporting the association between other metals and dementia (Continued)

the provincial health plan of

Quebec in 1994.

26 provinces and 3 municipal

districts of mainland Chin

Not specified.

68 participants with clinically-

diagnosed $A D$ and 68 age- and sex-

matched controls.

water was sampled four times in

1995-6 in 54 municipalities of SLS

Long-term exposure was estimated based on residential history.

Shen et al., 2014 [49] Aluminium

Aluminium

Mortality data from the Central Bureau of Statistics (1969-1983) and dementia patients within 112 psychiatric nursing homes (as collected by Norwegian Institute for Gerontology in 1982).

Wettstein et al., $1991 \quad$ Aluminium Residents of two Zurich city districts.

AD mortality in municipalities within $20 \mathrm{~km}$ of Alba based on national mortality statistics. Census data were used as a reference population.

Gillette-Guyonnet et al., Calcium 2005 [57]

Toulouse subset of the EPIDOS study cohort of women aged

$\geq 75$ years.

The IMAGE Project covering the population of Saguenay-Lac-SaintJean (SLSJ), Québec.

Not specified.

Crels in 1990 were related to AD mortality 1991-2000.

Cross-sectional study. Drinking water quality and acidification of lakes was related to st mortality rates.

775 men and women aged 82-85 years who had lived in that area for at least 15 years.

Not stated

Civita, Fiorucci, \& Mie, Aluminium 2001 [109]

Emard et al., 1994 [37] Cobalt
462 women from one centre of whom 60 developed clinically diagnosed AD. 323 had normal cognitive function and the remainder were lost to follow up.

129 individuals with AD (clinically diagnosed by standard medical services) who were born in SLSJ.
Cross-sectional study. Aluminium concentrations were measured in drinking water. The dementia outcome was measured using the truncated MMSE.

Cross-sectional study. A map of the location of deaths with $A D$ was released from $1 \mathrm{~kg}$ of clay at various sampling sites.

Prospective cohort study: logistic regression Water consumption based on self-report (at baseline and follow up) was combined with local tap water composition data. Dementia was clinically diagnosed.

Cross-sectional study: principal components analysis. Samples of aquatic sediment were analysed for geochemical variables. AD cases were identified from a registry. compared to levels of aluminium water (total Al, total dissolved Al total monomeric $\mathrm{Al}$, organic

monomeric Al, inorganic monomeric $\mathrm{Al}$, polymeric $\mathrm{Al}$, as well as the main monomeric inorganic forms) based on recent and long-term exposure, only recent exposure to monomeric organic aluminium was associated with $\mathrm{AD}$ at conventional levels (OR $95 \%$ Cl 2.67, 1.04-6.90).

Higher aluminium levels in soil were B associated with reduced $A D$ mortality (highest:lowest group RR $95 \%$ Cl: $0.267,0.265-0.268)$

Highest:lowest zone of aluminium concentration was associated with a raised standardised dementia mortality rate (per 10,000 inhabitants per year: 48.3 vs 32.4). The effect size was greater in women (59.4 vs 38.5) than men (36.9 vs 26.1).

No significant difference was observed between the participant groups on mnestic or naming subscores $(P=0.962$ and $P=0.567)$.

They found an increased SMR in the municipality compared to the province or the whole of Italy. They also noted that the areas with highest dementia mortality had the highest aluminium concentrations in water.

Women who developed AD showed B a decrease in daily calcium intake at

logistic regres found to be a predictor of dementia or if it wasn't included.

21 individuals with $A D$ were born in $B$ areas with lower than average concentration of cobalt; 20 were born in areas with higher than average concentrations. This difference is not statistically significant. 
Table 5 Individual studies reporting the association between other metals and dementia (Continued) $\begin{array}{lll}\text { Emard et al., } 1994 \text { [37] Copper } & \begin{array}{l}\text { The IMAGE Project covering the } \\ \text { population of Saguenay-Lac-Saint- }\end{array} & \text { diagnosed by standard medical }\end{array}$ Jean (SLSJ), Québec. services) who were born in SLSJ.

Loef \& Walach, $2012 \quad$ Copper $[24]$

Emard et al., 1994 [37] Iron

Shen et al, $2014[49]$ Iron

municipa districts of mainland China.

Systematic review of studies relating iron to $A D$ from 11 databases.

Not specified.

26 provinces and 3 municipa districts of mainland China.

Systematic review of studies relating copper to $A D$ from 11 databases.

The IMAGE Project covering the population of Saquenay-Lac-SaintJean (SLSJ), Quebec.

129 individuals with AD (clinically diagnosed by standard medical services) who were born in SLSJ.

2 meta analyses, 2 systematic case-control studies, 30 autopsy study.

Not specified.

101 studies:

2 meta analyses, 2 systematic geochemical variables. AD cases reviews, 11 RCTs, 2 prospective studies, 3 cross-sectional studies, 45 studies,5 uncontrolled studies, 1 case reviews, 11 RCTs, 2 prospective studies, 3 cross-sectional studies, 45 case-control studies, 30 autopsy studies, 5 uncontrolled studies, 1 case study.
Cross-sectional study: principal components analysis. Samples of aquatic sediment were analysed for were identified from a registry.

18 individuals with $A D$ were born in $B$ areas with lower than average concentration of copper; 30 were born in areas with higher than average concentrations. This difference is not statistically significant

Cross-sectional study. Soil chemical Copper concentration correlated levels in 1990 were related to AD with annual AD mortality after three mortality 1991-2000. outlier provinces were removed $(r=$ $0.449, P=0.021$.

Systematic review.

Of relevant evidence that is reviewed, the authors conclude that "In summary, the current trials provide no conclusive evidence that depletion or supplementation of $\mathrm{Cu}$ is beneficial for AD... [t]he specific outcomes for $\mathrm{Cu}$ are more conflicting; while evidence suggests conflicting; while evidence sugge
that the systemic Cu level is that the systemic Cu level is
increased in patients with $A D$, further research is needed to define the alterations of $\mathrm{Cu}$ in the brain during AD." (p.6).

Cross-sectional study: principal components analysis. Samples of aquatic sediment were analysed for geochemical variables. AD cases were identified from a registry.

16 individuals with $A D$ were born in $B$ areas with lower than average concentration of iron; 35 were born in areas with higher than average concentrations. This difference was statistically significant $(P<0.05)$.

Cross-sectional study. Soil chemical levels in 1990 were related to AD mortality 1991-2000.

Higher iron levels in soil were associated with increased AD mortality (highest:lowest group RR 95 \% Cl: 1.248, 1.245-1.251). Iron concentration correlated with annual AD mortality after three outlier provinces were removed $(r=0.537$, $P=0.007)$.

Systematic review.

"In summary, the current trials provide no conclusive evidence that depletion or supplementation of ... Fe is beneficial for AD... Fe has been consistently found at elevated levels in the brains of AD sufferers by both topsy and case-control studies." (p.6). 
Table 5 Individual studies reporting the association between other metals and dementia (Continued)

Emard et al., 1994 [37] Manganese The IMAGE Project covering the 129 individuals with AD (clinically Jean (SLSJ), Québec. services) who were born in SLSJ.

Emard et al., 1994 [37] Molybdenum The IMAGE Project covering the population of Saguenay-Lac-SaintJean (SLSJ), Québec.

129 individuals with $A D$ (clinically diagnosed by standard medical services) who were born in SLSJ.

Emard et al., 1994 [37] Nickel

The IMAGE Project covering the population of Saguenay-Lac-SaintJean (SLSJ), Québec.

129 individuals with AD (clinically diagnosed by standard medical services) who were born in SLSJ.

Emard et al., 1994 [37] Uranium

The IMAGE Project covering the 129 individuals with AD (clinically population of Saguenay-Lac-Saint- diagnosed by standard medical Jean (SLSJ), Québec. services) who were born in SLS.

Emard et al., 1994 [37] Zinc

The IMAGE Project covering the population of Saguenay-Lac-SaintJean (SLSJ), Québec.

129 individuals with AD (clinically diagnosed by standard medical services) who were born in SLSJ.

Shen et al., 2014 [49] Zinc

26 provinces and 3 municipa

Not specified. districts of mainland China.
Cross-sectional study: principal compon alysis. Samples of geochemical variables. AD cases were identified from a registry.

Cross-sectional study: principal components analysis. Samples of aquatic sediment were analysed for geochemical variables. AD cases were identified from a registry.

Cross-sectional study: principal components analysis. Samples of aquatic sediment were analysed for geochemical variables. AD cases were identified from a registry.

Cross-sectional study: principal components analysis. Samples of aquatic sediment were analysed for geochemical variables. AD cases were identified from a registry.

Cross-sectional study: principal components analysis. Samples of aquatic sediment were analysed for geochemical variables. AD cases were identified from a registry.

Cross-sectional study. Soil chemical levels in 1990 were related to $A D$ mortality 1991-2000.
12 individuals with $A D$ were born in $B$ areas with lower than average concentration of manganese; 35 were born in areas with higher than average concentrations. This difference was statistically significant $(P<0.05)$

29 individuals with $A D$ were born in $B$ areas with lower than average concentration of molybdenum; 16 were born in areas with higher than average concentrations. This difference is not statistically significant.

27 individuals with $A D$ were born in $B$ areas with lower than average concentration of nickel; 29 were born in areas with higher than average concentrations. This average concentrations. This
difference is not statistically significant.

10 individuals with $A D$ were born in $B$ areas with lower than average concentration of uranium; 9 were born in areas with higher than average concentrations. This difference is not statistically significant.

29 individuals with $A D$ were born in $B$ areas with lower than average

concentration of aluminium; 30 were

born in areas with higher than

average concentrations. This

difference is not statistically significant.

Higher zinc levels in soil were associated with increased $A D$ mortality (highest:lowest group RR $95 \%$ Cl: 2.289, 2.275-2.303). 
Table 6 Individual studies reporting the association between other trace elements and dementia

\begin{tabular}{|c|c|c|c|}
\hline Study & Exposure & Sample description & $N$ \\
\hline $\begin{array}{l}\text { Still \& Kelley, } \\
1980[51]\end{array}$ & Fluoride & $\begin{array}{l}\text { All first admissions of people aged } \\
\geq 55 \text { years to South Carolina } \\
\text { Department of Mental Health } \\
\text { hospitals from three counties who } \\
\text { had lived in that county for at least } \\
10 \text { years. }\end{array}$ & $\begin{array}{l}\text { Case records for } 160 \text { patients } \\
\text { were examined and, based on } \\
\text { that evidence, } 67 \text { were } \\
\text { diagnosed with a primary } \\
\text { degenerative dementia, i.e. AD. }\end{array}$ \\
\hline $\begin{array}{l}\text { Loef, Schrauzer, } \\
\& \text { Walach, } 2011 \\
\text { [23] }\end{array}$ & Selenium & $\begin{array}{l}\text { Systematic review of studies relating } \\
\text { selenium to } A D \text { from } 8 \text { databases. }\end{array}$ & $\begin{array}{l}56 \text { studies: } 9 \text { placebo-controlled, } \\
4 \text { prospective, } 4 \text { cross-sectional, } \\
15 \text { case-control, and } 24 \text { autopsy } \\
\text { studies. }\end{array}$ \\
\hline
\end{tabular}

Gillette-Guyonnet Silica et al., 2005 [57]

Rondeau et al., Silica 2009 [39]

Taylor et al. 1995 [48]
Toulouse subset of the EPIDOS study cohort of women aged $\geq 75$ years.

whomen from one centre of whom 60 developed clinically diagnosed AD. 323 had norm

remainder were lost to follow up.

PAQUID: A community-based cohort of 3,777 elderly people aged $\geq 65$ years in SW France.

Same cohort as Forster et al., 1995 [47]

1925 individuals of whom 461 developed clinically diagnosed dementia (364 AD). 214 addresses of the 218 cases

Methodology/design

Finding

Cross-sectional study. Annual incidence of Horry County was reported to have

based on the admissions data. These were compared to Anderson $(0.49 \pm 0.10 \mathrm{mg} / \mathrm{l})$ then compared with fluoride and York $(0.61 \pm 0.12 \mathrm{mg} / \mathrm{l})$ Counties. It

concentrations in public water supplies also has the lowest calculated annula (time of measurement is not given). incidence of dementia per 100,000

population (3.6; Anderson 20.8, York 17.1).

Systematic review.

One double-blind RCT is reported (PREAD- -

VISE[52-54]) but this seems to have

subsequently converted into an

observational study.

A prospective cohort study is referred to

by citing a conference abstract [55] subsequent reports do not focus on selenium.[56]

Of 15 case-control studies, the authors comment that "four studies reported about increased levels of Se-concentration or GPx-activity while the majority found decreased levels, albeit non-significant in some studies." (p. 87).

Of the 24 autopsy studies, the authors conclude that "the autopsy studies do not yield a consistent picture of whether, how and where in brain Se levels become altered in subjects with AD." (p. 87).

Low silica consumption in water $(\leq 4 \mathrm{mg}$ vs $>12$ mg per day) was associated with Prospective cohort study: logistic regression. Water consumption based on self-report (at baseline and follow up) was diagnosed.

(multivariable-adjusted OR, $95 \% \mathrm{Cl}: 2.74$ 1.09-6.86). Women who developed AD had lower silica intake at baseline and showed a decrease in daily silica intake at showed a

Prospective cohort study: Cox PH models. Mean levels of silica in drinking water over the previous decade based on current residential location was linked to incident dementia over 15 years follow up.

Highest:lowest quartile of silica in drinking $A$ water was associated with an increased isk of dementia and AD (multivariableadjusted HR, $95 \%$ Cl: 1.33, 1.01-1.74; 1.33, 0.98-1.80).

There were no differences in silica concentrations in samples for cases or controls and no association between

Water samples were obtained for Cross-sectional study (case-control). Aluminium concentration in water samples drawn from the place of increased levels of silica and dementia within 10 years prior to onset of dementia $(\mathrm{OR}, 95 \% \mathrm{Cl} \geq 3 \mathrm{mg} / \mathrm{L} 0.8,0.34-1.83$ ). (or equivalent date for controls). 
Table 6 Individual studies reporting the association between other trace elements and dementia (Continued)

\begin{tabular}{|c|c|c|c|c|c|c|}
\hline $\begin{array}{l}\text { Martyn et al., } \\
1997 \text { [46] }\end{array}$ & Silicon & $\begin{array}{l}\text { Participants were selected from CT } \\
\text { records of eight neuroradiology } \\
\text { centres in the UK. }\end{array}$ & $\begin{array}{l}\text { A total of } 872 \text { men ( } 106 \text { AD, } 99 \\
\text { other dementia, } 226 \text { brain cancer, } \\
441 \text { other disease of the nervous } \\
\text { system) }\end{array}$ & $\begin{array}{l}\text { Cross-sectional study (case-control): } \\
\text { logistic regression. Average levels of } \\
\text { silicon in drinking water based on } \\
\text { residential history (after age } 25 \text { years) was } \\
\text { related to diagnosis based on hospital } \\
\text { records. }\end{array}$ & $\begin{array}{l}\text { There were no associations identified } \\
\text { between silicon concentrations } \\
\text { consistently above } 6 \mathrm{mg} / \mathrm{L} \text { (compared to } \\
\text { lower levels) with each of the three } \\
\text { comparison groups (e.g. AD vs other } \\
\text { diagnoses (adjusted-OR, } 95 \% \mathrm{Cl} \text { : } 0.94 \text {, } \\
0.39-2.26 \text { ). }\end{array}$ & B \\
\hline
\end{tabular}

AD Alzheimer's dementia, $C l$ confidence interval, $C T$ computed tomography, $H R$ hazard ratio, $O R$ odds ratio, $P H$ proportional hazards, $R C T$ randomized, controlled trial, $R R$ relative risk, SD standard deviation, $S M R$ Standardised Mortality Ratio, UK United Kingdom 
Table 7 Individual studies reporting the association between occupational exposures and dementia

\begin{tabular}{|c|c|c|c|c|}
\hline Study & Exposure & Sample description & N & Methodology/design \\
\hline $\begin{array}{l}\text { Peters et al., } \\
2013 \text { [60] }\end{array}$ & $\begin{array}{l}\text { Aluminium (occupational } \\
\text { exposure) }\end{array}$ & $\begin{array}{l}\text { Survey information } \\
\text { collected from miners } \\
\text { living in Kalgoorlie, } \\
\text { Western Australia. Data } \\
\text { collected in } \\
1961, ' 62,74,75 \text { and } \\
2000 \text {. }\end{array}$ & $\begin{array}{l}1894 \text { ever underground gold miners } \\
\text { linked with Western Australian } \\
\text { Registrar General's Mortality Database } \\
\text { of whom } 16 \text { died with AD. }\end{array}$ & $\begin{array}{l}\text { Retrospective cohort study: SMRs and } \\
\text { Cox PH models. Exposure to } \\
\text { aluminium dust ascertained by self- } \\
\text { report. }\end{array}$ \\
\hline $\begin{array}{l}\text { Salib et al., } \\
1996[61]\end{array}$ & $\begin{array}{l}\text { Aluminium (occupational } \\
\text { exposure) }\end{array}$ & $\begin{array}{l}\text { Individuals referred to } \\
\text { a psychogeriatric unit } \\
\text { in Warrington, UK }\end{array}$ & $\begin{array}{l}198 \mathrm{AD}, 194 \text { other dementia, } 176 \\
\text { unmatched controls. }\end{array}$ & $\begin{array}{l}\text { Cross-sectional study (case-control). } \\
\text { Occupation based on self-report. }\end{array}$ \\
\hline $\begin{array}{l}\text { Graves et al., } \\
1998 \text { [58] }\end{array}$ & $\begin{array}{l}\text { Aluminium (occupational } \\
\text { exposure) }\end{array}$ & $\begin{array}{l}\text { Subsample of Kukull et } \\
\text { al.'s cohort [71]. }\end{array}$ & $89 \mathrm{AD}$ and 89 matched controls. & $\begin{array}{l}\text { Cross-sectional study (case-control). } \\
\text { Aluminium exposure rated blind } \\
\text { based on occupational history. }\end{array}$ \\
\hline $\begin{array}{l}\text { Gun et al., } \\
1997 \text { [59] }\end{array}$ & $\begin{array}{l}\text { Aluminium (occupational } \\
\text { exposure) }\end{array}$ & $\begin{array}{l}\text { Men and women } \\
\text { recruited from Sydney } \\
\text { hospitals 1986-1989. }\end{array}$ & $\begin{array}{l}170 \text { probable or possible } A D \text { and } 170 \\
\text { controls. }\end{array}$ & $\begin{array}{l}\text { Cross-sectional study (case-control). } \\
\text { Aluminium exposure was derived } \\
\text { from an occupational interview. }\end{array}$ \\
\hline
\end{tabular}

Finding

ium dust inhalation was

associated with increased AD

mortality (SMR, $95 \%$ Cl: 1.38, 0.69

2.75). There was also an association

between inhaled aluminium dust and

AD mortality in Cox models (HR, $95 \%$

Cl: 2.76, 0.88-8.82).

No association was found between

working in the aluminium industry

and $\mathrm{AD}(\mathrm{OR}, 95 \% \mathrm{Cl}: 0.98,0.53-1.75)$

This was also the case for all

dementias

There was an association between

ever exposure to aluminium and $A D$

(OR, $95 \%$ Cl: 1.46, 0.62-3.42) but not

in models which took into account

intensity, duration, or age at exposure.

from an occupational interview.

Aluminium exposure was associated

with a reduced odds ratio of $A D(O R$

$95 \%$ Cl: $0.33,0.01-4.16)$. This study

has very low statistical power because

only four cases and controls were

exposed. Probable and Possible AD

cases considered together.

Exposure to defoliants/fumigants was A associated with an increased risk of AD (multivariable-adjusted RR, $95 \%$

Cl: $4.35,1.05-17.90)$ random sample from which time 36 developed probable or provincial health possible AD (clinically diagnosed)

Exposures based on self-repo

2001 [62]

insurance records.

Koeman et al.

Diesel motor exhaust (DME) The Netherlands

Cohort Study which

consisted of 120,852

individuals aged 55-69

682 men and 870 women who had died with non-VaD reported on their

Case-cohort study: Cox PH models. Exposures based on self-report

Exposure to DME compared to no exposure was not associated with an increased risk of non-VaD mortality in

Dementia status ascertained using men or women

years in 1986

calculated from a randomly-selected sub-cohort.

682 men and 870 women who had Case-cohort study: Cox PH models.

The Netherlands

Cohort Study which consisted of 120,852

individuals aged 55-69 years in 1986

died with non-VaD reported on their death certificates over 17 years follow

Exposures based on self-report.

Low or high exposure to ELF-MF A compared to no exposure was not associated with an increased risk of non-VaD mortality in men (adjusted HR, 95 \% Cl 1.26, 1.01-1.57; 1.40, 0.922.14) but not in women. Conversely, an association was seen for electrical shocks for women $(1.25,0.85-1.84$

$11.1,3.84-32.2)$ but not men

The hazard associated with

cumulative ELF-MF exposure to

showed no trend $(P=0.09)$. 
Table 7 Individual studies reporting the association between occupational exposures and dementia (Continued)

\section{The Manitoba Study of}

Tyas et al.,

$2001[62]$

Excessive noise

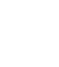

McDowell et al., Glues and pesticides/ 1994 [66] fertilizers Health and Aging random sample from provincial health insurance records. for five years, during possible AD (clinically diagnosed).

\section{Expos}

258 people clinically diagnosed with

$\begin{array}{ll}\begin{array}{ll}\text { Gauthier et al., } & \text { Herbicides, insecticides } \\ \text { pesticides }\end{array} \\ & \\ & \\ \text { Santibanez et al., } & \text { Lead (occupational } \\ 2007 \text { [68] } & \text { exposure) }\end{array}$

Koeman et al. Metals (occupational 2015 [63] exposure)

Hayden et al., Pesticides 2010 [65]

Baldi et al.

Pesticides

$2003[70]$
The Cache County study (Utah, USA).

3,084 individuals aged $\geq 65$ years without dementia followed up over 10 years during which time 500 people developed clinicallydiagnosed dementia (344 AD).

PAQUID cohort [110]. $\quad 96$ incident cases of AD from 1,507 Male and female residents of Gironde,
96 incident cases of AD from 1,507
contactable individuals between 5and 10-year follow-up.
Canadian Study of Health and Aging based in 10 provinces. probable AD (less than three years since onset of symptoms) and 535 age-matched controls (stratified by study centre, community-/institutiondweller and clinically confirmed to be cognitively normal)

1924 people aged $\geq 70$ years old were screened and examined in the Saguenay-Lac SaintSaguenay-Lac Saint-
Jean region (Québec, Canada).

Systematic review of studies linking occupational exposures and AD.

The Netherlands Cohort Study which consisted of 120,852

122 people clinically diagnosed with $\mathrm{AD}$ and 122 age-matched controls ( \pm 2 years). 67 case-control pairs hade complete data and were included in the models.

Twenty four studies: 3 cohort and 21 Systematic review. case-control studies.

682 men and 870 women who had died with non-VaD reported on their death certificates over 17 years follow up. pesticides (multivariable adjusted $O R_{2}$ individuals aged $55-69$

years in 1986.
Occupational exposure to glues and Exposures based on self-report. De
Prospective longitudinal study. Exposures based on self-repor.

Cross-sectional study (case-control): ogistic regression. Risk factor exposure gathered by questionnaire self-report.

Cross-sectional study (case-control): logistic regression. Exposure to history and census data (1971-91) on $95 \%$ Cl: 1.07, 0.39-2.54); 1.62 (0.64-

herbicide and insecticide spraying in 4.11$) ; 0.97(0.38-2.41)$. the area.

Occupational exposure to excessive noise was associated with a decreased risk of $\mathrm{AD}$ (multivariableadjusted RR, $95 \% \mathrm{Cl}$ : 0.12, 0.02-0.96). N.B. only one case was exposed to excessive noise. pesticides/fertilizers was associated with an increased risk of $A D$ (multivariable-adjusted OR, 95\%Cl: glues 1.80, 0.99-3.27; pesticides/ fertilizers 1.58, 0.81-3.10. Stratifying by education showed higher risk in those with less education.

No increased risk of AD with exposure $B$

"For lead exposure there are no data supporting any association. All the studies are case-control studies, with a relatively low level of quality according to our classification." (p. 730)

Case-cohort study: Cox PH models. mentia status ascertained using death certification. Person-years at risk were calculated from a randomly-selected sub-cohort.

Prospective cohort study: $\mathrm{Cox} \mathrm{PH}$ models. Exposures based on selfreport. Follow-up conducted at 3,7 and 10 years from baseline.

Low or high exposure to metals compared to no exposure was associated with an increased risk of non-VaD mortality in men (adjusted HR, 95 \% Cl 1.21, 0.84-1.74; 1.35, 0.981.86) and women $(4.55,1.35-15.3 ; 1.78$ 0.23-13.8).

The hazard associated with cumulative exposure to metals showed a significant trend $(P=0.01)$.

Pesticide exposure was associated with an increased risk of dementia (adjusted HR, 95 \% Cl 1.38, 1.09-1.76) and $A D(1.42,1.06-1.91)$. A slightly greater risk associated with organophosphates for AD was reported.

Prospective cohort study.

Occupational exposure to pesticides was associated with an increased risk of $A D$ in men (adjusted RR, $95 \% \mathrm{Cl}$ :

(1)

A


Table 7 Individual studies reporting the association between occupational exposures and dementia (Continued)

France aged $\geq 65$ in

1987.

Koeman et al. Pesticides

2015 [63]

The Netherlands

individuals aged 55-69

years in 1986.

682 men and 870 women who had died with non-VaD reported on their

.

Cohort Study which

consisted of 120,852 death certificates over 17 years follow

Cumulative exposure to pesticides was calculated base AD was diagnosed by a neurologist.

Case-cohort study: Cox PH models. Exposure based on self-report. Dementia status ascertained using death certification. Person-years at risk were calculated from a randomly-selected sub-cohort.

British farmers in the 1,350 individuals born before 1958 . 1970s.

Review of studies linking pesticide exposure and dementia.
2.4, 1.0-5.6). This was not the case for $24,1.0-5.6$. This was not the case for

Exposure to any pesticides was not associated with an increased risk of non-VaD mortality in men or women. The same pattern was seen when disaggregating the effect of insecticides, herbicides, and fungicides in men. In women, high exposure to herbicides and fungicides was associated with an increased risk of non- $\mathrm{VaD}$ mortality (adjusted $\mathrm{HR}$, $95 \%$ Cl 5.27, 1.30-21.4; 2.83, 0.87-9.16).

The hazard associated with cumulative exposure showed significant trend for all pesticides and individual types $(P=0.01)$ but the individual types $(P=0.01)$ but the
trend was reversed with increasing exposure associated with a lower risk.
In people who had never sought advice for pesticide poisoning, handling pesticide concentrate was

Retrospective cohort study: logistic regression. Exposure was based on self-reported levels of

organophosphate exposure. Low dose chronic exposure was defined as handling organophosphate concentrate and acute exposure as having sought advice for pesticide poisoning. Dementia was identified by a screening questionnaire.

Fourteen studies are reviewed (2 on Narrative review. cognitive performance, 1 mild cognitive dysfunction, 7 AD, 1 FTD, 2 $\mathrm{cognitive}$ dysfun
$\mathrm{VaD}$, and $1 \mathrm{PD}$ ).
However, in those who had handled pesticide concentrate, seeking advice for pesticide poisoning was associated with an increased risk of dementia (adjusted OR, $95 \% \mathrm{Cl} 4.27$, 1.85-9.83).

Of the $7 \mathrm{AD}$ studies, 5 demonstrated an increased risk of $A D$ (plus one which did so weakly) and one showed no association.

"Information from the literature [on $\mathrm{VaD}]$ is scant; however, occupational exposure to pesticides or fertilizers exposure to pesticides or fertilizers
conferred a two-fold increased risk of conferred a two-fold increased risk of
developing vascular dementia in the Canadian Study of Health and Aging." (p. 7).

"Due to the relative rarity of [FTD] at the population level, pesticide exposure has been studied as a contributing factor to FTD onset in relatively few studies and no association was found." (p. 7). 
Table 7 Individual studies reporting the association between occupational exposures and dementia (Continued)

\begin{tabular}{llll}
\hline Santibanez et al., Pesticides & $\begin{array}{l}\text { Systematic review of } \\
\text { studies linking } \\
\text { occupational exposures }[68] \\
\text { and AD. }\end{array}$ & $\begin{array}{l}\text { Twenty four studies: } 3 \text { cohort and } 21 \\
\text { case-control studies. }\end{array}$ & \\
& &
\end{tabular}

Tyas et al., Pesticides/fertilizers, inks/ 2001 [62]

Tyas et al.,

2001 [62]

Kukull et al. Solvents

1995 [71]

Solvents

dyes, paints/stains/varnishes, gasoline/fuels/oils, solvents/ degreasers, liquid plastics/

vibratory tools

Radiation

The Manitoba Study of Health and Aging random sample from provincial health insurance records.

Individuals aged $\geq 60$ years recruited to the Group Health Cooperative in Seattlearea clinics.

Koeman et al. Solvents 2015 [63]
The Netherlands Cohort Study which consisted of 120,852 individuals aged 55-69 years in 1986

694 cognitively-intact older adults

Prospective longitudinal study. Exposures based on self-report.

$\begin{array}{ll}\text { Health and Aging - } & \text { followed up for five years, during } \\ \text { random sample from } & \text { which time } 36 \text { developed probable or }\end{array}$

$\begin{array}{ll}\text { Health and Aging - } & \text { followed up for five years, during } \\ \text { random sample from } & \text { which time } 36 \text { developed probable or }\end{array}$ possible AD (clinically diagnosed).

random sample from
provincial health 
"For solvents, only two out of the 11 occupational exposures and $A D$.

AD Alzheimer's disease, Cl confidence interval, ELF-MF Extremely low frequency magnetic fields, FTD fronto-temporal dementia, $H R$ hazard ratio; $O R$ odds ratio, $P D$ Parkinson's disease, $R R$ relative risk, VaD 730)

vascular dementia 
Table 8 Individual studies reporting the association between miscellaneous exposures and dementia

\begin{tabular}{|c|c|c|c|c|}
\hline Study & Exposure & Sample description & $N$ & Methodology/design \\
\hline $\begin{array}{l}\text { Salib \& Sharp, } \\
1999 \text { [72] }\end{array}$ & Climate & $\begin{array}{l}\text { Daily hospital admissions } \\
\text { from North Cheshire to a } \\
\text { single hospital. Dementia } \\
\text { cases were identified by } \\
\text { ICD-9 code } 290 .\end{array}$ & $\begin{array}{l}\text { 189/2070 psychiatric } \\
\text { admissions during } 1993 \text { were } \\
\text { coded as being related to } \\
\text { dementia. }\end{array}$ & $\begin{array}{l}\text { UK Meteorological Office data were collect } \\
\text { at Manchester airport ( } 30 \text { miles away) every } \\
\text { day. }\end{array}$ \\
\hline $\begin{array}{l}\text { Huss et al., } \\
2009[74]\end{array}$ & $\begin{array}{l}\text { Magnetic } \\
\text { field } \\
\text { exposure } \\
\text { (220-380 kV) } \\
\text { through } \\
\text { power lines }\end{array}$ & $\begin{array}{l}\text { Swiss National Cohort from } \\
2000-5 \text {. The study } \\
\text { population comprised } 4.65 \\
\text { million individuals and } \\
22,821,824 \text { person-years. }\end{array}$ & $\begin{array}{l}29,975 \text { dementia deaths } \\
\text { were recorded, including } \\
9,228 \text { AD deaths. }\end{array}$ & $\begin{array}{l}\text { Prospective cohort study: Cox PH models. } \\
\text { Exposure was based on distance of place o } \\
\text { residence to the nearest power line and } \\
\text { duration of exposure }(5,10 \text {, or } 15 \text { years). } \\
\text { Dementia was ascertained from death } \\
\text { certification. }\end{array}$ \\
\hline
\end{tabular}

Vergara et al., Extremely $2013[111] \quad$ low

frequency

magnetic

fields

Garcia et al., Extremely

low

frequency

electric and

magnetic

fields.

Schuez et al., Mobile

2009 [75] phones

Afzal et al.,

2014 [76]

Vitamin D

Systematic review of studies $20 \mathrm{AD}$ and 9 dementia of occupational exposure to studies.

magnetic fields and

neurodegenerative disease.

Systematic review and metaanalysis

All mobile phone subscriptions in Denmark, 1982-1995.

Danish general population sample recruited to the

Copenhagen Heart Study baseline (1981 to 1983).

Littlejohns et al., Vitamin D 2014 [78]

Healthy participants in the US population-based Cardiovascular

Health Study.

Toulouse subset of the EPIDOS study cohort of women aged $\geq 75$ years. code during follow up.
Annweiler et al., Vitamin D 2011 [77]
Fourteen studies: 9 casecontrol, 5 cohort

Systematic review.

Finding

There were no associations found between

weather parameters and hospital admissions of

people with dementia.

Proximity to power lines was associated with

an increased risk of dementia but this was not

statistically significant at conventional levels

(adjusted HR, $95 \% \mathrm{Cl}$ closest:most distant

categories 1.23, 0.96-1.59). Longer duration

increased the magnitude of this association

$(\geq 15$ years at this place of residence $2.00,1.21$ 3.33).

Systematic review and meta-analysis.

There was a small association between

occupational magnetic field exposure and $\mathrm{AD}$ based on a meta-analysis (RR, $95 \% \mathrm{Cl} 1.27$ $1.15-1.40)$. There was no clear association with dementia (1.05, 0.96-1.14)

Pooled cohort risk estimates (OR, 95 \% Cl 1.62, $1.16-2.27)$. Pooled case-control risk estimates $(2.03,1.38-3.00, P=0.004)$

420,095 private mobile phone subscribers of whom

532 were admitted to

Prospective cohort study. Mobile phone use Pas derived from subscription records. hospital with a dementia .

admission records.

10,186 participants, of whom Prospective cohort study: Cox PH models.

418 developed $A D$ and $92 \quad$ Baseline plasma vitamin $D$ levels were related developed to VaD. derived from diagnostic codes recorded on the national Danish Patient Registry.

1658 adults followed up for Prospective cohort study: Cox PH models. mean 5.6 years during which Serum vitamin D levels were measured at time 171 developed

clinically-ascertained dementia (102 AD).

40 participants, of whom 6 Prospective cohort study: logistic regression. developed non-AD (and Baseline serum vitamin D was related to $4 \mathrm{AD}$ ) at clinical assessment incident non-AD dementia. over 7 years follow up.
Mobile phone use was associated with a

decreased risk of being hospitalised with $A D$

(Standardized hospitalization ratio, $95 \% \mathrm{Cl} 0.7$

"other dementia".

Lower plasma vitamin D levels were associated A with an increased risk of $\mathrm{AD}\left(\mathrm{HR}, 95 \% \mathrm{Cl}<25^{\text {th }}\right.$

percentile [seasonally-adjusted] vs $>50^{\text {th }} 1.29$,

$1.01-1.66 ; P=0.03)$. Similar findings were

reported for $\operatorname{VaD}(1.22,0.79-1.87 ; P=0.42)$ and all dementia $(1.27,1.01-1.60 ; P=0.02)$

Being deficient (25-50nM) or severely deficient A

$(<25 \mathrm{nM})$ in vitamin $\mathrm{D}$ was associated with an increased risk of incident AD (multivariableadjusted HR, 95 \% Cl: 1.69, 1.06-2.69; 2.22, 1.024.83; $\left.P_{\text {trend }}=0.008\right)$. Similar results were seen for all-cause dementia $(1.53,1.06-2.21 ; 2.25$,

$$
\text { 1.23-4.13; } P_{\text {trend }}=0.002 \text { ). }
$$

Vitamin D deficiency at baseline was

associated with an increased risk of non-AD dementia (adjusted OR, $95 \%$ Cl 19.57, 1.11343.69; $P=0.042$ ).
0.6-0.9). Similar results were seen for VaD and 
Table 8 Individual studies reporting the association between miscellaneous exposures and dementia (Continued)

\begin{tabular}{|c|c|c|c|c|c|c|}
\hline $\begin{array}{l}\text { Wilkins et al., } \\
2006 \text { [79] }\end{array}$ & Vitamin D & $\begin{array}{l}\text { Participants recruited from } \\
\text { greater metropolitan St } \\
\text { Louis, MO by the } \\
\text { Washington University AD } \\
\text { Research Center. }\end{array}$ & $\begin{array}{l}40 \text { people with clinically } \\
\text { diagnosed mild } A D \text { and } 40 \\
\text { without dementia. }\end{array}$ & $\begin{array}{l}\text { Cross-sectional study (case-control): logistic } \\
\text { regression and general linear model. Serum } \\
\text { vitamin D levels were measured. }\end{array}$ & $\begin{array}{l}\text { Vitamin D status was not associated with } A D \\
\text { (multivariable-adjusted OR, } 95 \% \text { Cl: deficient } \\
\text { vs sufficient } 2.80,0.64-12.28 \text {; insufficient vs } \\
\text { sufficient } 1.78,0.61-5.19) \text {. Vitamin } D \text { status was } \\
\text { associated with CDR sum of boxes }(P=0.0468) ; \\
\text { and the Short Blessed Test }(P=0.0077) \text { but not } \\
\text { others tests. }\end{array}$ & B \\
\hline $\begin{array}{l}\text { Frecker, } \\
1991[42]\end{array}$ & Water pH & $\begin{array}{l}\text { Mortality records in } \\
\text { Bonavista Bay, } \\
\text { Newfoundland, 1985-86. }\end{array}$ & $\begin{array}{l}191 \text { dementia deaths in } \\
1985,208 \text { deaths in } 1986\end{array}$ & $\begin{array}{l}\text { Cross-sectional study. Place of birth of all } \\
\text { individuals dying with dementia was identified } \\
\text { and associated with drinking water samples at } \\
\text { those locations from } 1986 .\end{array}$ & $\begin{array}{l}\text { The area with the highest dementia mortality } \\
\text { ( } 37.5 \% \text { in } 1985 \text { and } 68.8 \% \text { in 1986) also had } \\
\text { the lowest pH of drinking water (5.2). This } \\
\text { association was not assessed for statistical } \\
\text { significance, but was argued to not be } \\
\text { confounded by age, sex or place of residence } \\
\text { stated on death certificate. }\end{array}$ & B \\
\hline
\end{tabular}

$A D$ Alzheimer's disease, $C l$ confidence interval, $H R$ hazard ratio, $O R$ odds ratio, $P H$ proportional hazards, UK United Kingdom, VaD vascular dementia 
uranium are not associated with an increased risk of dementia, but this is often based on minimal evidence. One prospective study and the larger cross-sectional studies tend to support an association between aluminium and dementia risk [39-41, 44].

\section{Other trace elements}

Table 6 shows the studies investigating links between other trace elements and dementia. A cross-sectional study extrapolated from the medical records of 160 people to estimate annual dementia incidence and found the area with the highest fluoride concentrations in public water supplies had the lowest incidence [51]. Selenium has been the focus of a number of studies. The included review article [23] referred to a randomised, controlled trial of selenium supplementation to reduce dementia risk, the PREADVISE trial, but this seems to have converted into an observational study and is yet to report on selenium levels [52-54]. The review also referred to a conference abstract reporting a prospective cohort study [55], but subsequent reports do not focus on selenium [56]. In general, this review article reported mixed findings from 15 case-control studies and 24 autopsy studies [23].

One cross-sectional study found no differences in average levels of silicon in drinking water between a group of people with Alzheimer's dementia and several neurological control groups [46]. On the other hand, two prospective cohort studies found an association between higher levels of silica in drinking water and dementia incidence $[39,57]$. However, a case-control study did not corroborate these findings [48].

The evidence for other trace elements is again mixed and generally weak in strength.

\section{Occupational-related exposures}

Table 7 summarises the individual studies relating occupational exposures to dementia risk. Four studies investigated occupational exposure to aluminium in relation to dementia [58-61]. These tended to be small with consequently low statistical power. Their results were mixed. The prospective Manitoba Study of Health and Aging studied a variety of exposures but the only robust association they found was an increased risk of dementia in relation to self-reported exposure to defoliants/fumigants [62]. The same study reported null associations in all other exposures studied, apart from a protective effect of excessive noise and increased risk associated with radiation exposure. However, in both these cases, only one person with dementia had been exposed to noise or radiation and so there is very limited statistical power. A case-cohort study of 1552 people dying with non-vascular dementia found no association between exposure to diesel motor exhaust fumes and dementia but mixed evidence for extremely low frequency magnetic fields or electric shocks [63]. Two reviews concluded that exposure to pesticides was associated with an increased risk of dementia which was corroborated by the prospective Canadian Study of Health and Aging, Cache County Study, the PAQUID study, and to some extent a retrospective British study of farmers but not by the Manitoba study or a case-control study from Québec; a study from the Netherlands had mixed findings [62-70]. A systematic review found no support for an association between occupational exposure to lead and dementia and mixed evidence (predominantly null) between solvent exposure and dementia [68]. A case-control study from the USA found an association between solvent exposure and $\mathrm{AD}$, at least in men [71]. However, a case-cohort study from the Netherlands found mixed associations between solvents and dementia, perhaps reflecting the diversity of chemicals described as solvents [63].

The evidence linking occupational exposures and dementia is frequently weak. Aside from the mixed evidence for solvents, the strongest evidence is for exposure to pesticides, but even findings in that literature are mixed. However, there seems to be no published evidence suggesting that occupational exposure to diesel motor exhaust, lead, inks/dyes, paints/stains/varnishes, gasoline/ fuels/oils, liquid plastics/rubbers, or vibratory tools affect dementia risk.

\section{Miscellaneous environmental factors}

Table 8 summarises studies linking miscellaneous environmental exposures and dementia. One study reported no association between climate and dementia admissions [72]. Two systematic reviews examined low and extremely low frequency electric and magnetic fields and, while the evidence is mixed, there seems to be an association with dementia risk and this was corroborated by a prospective study in Switzerland which found that living close to power lines for over 15 years was associated with a doubling of Alzheimer's disease mortality (but not the occupational study mentioned above [63]) [73, 74]. Its findings are difficult to interpret, but a prospective study in Denmark found that mobile phone subscription was associated with a decreased risk of subsequent hospital admission with dementia [75]. Three high quality prospective studies (including 11,884 people of whom 691 developed dementia) examined the association between vitamin $\mathbf{D}$ and dementia and all found that lower vitamin $D$ levels at baseline were associated with an increased risk of developing dementia [76-78]. However, this finding was not corroborated by a small case-control study (40 in each group) of people with mild dementia [79]. Finally, one study noted that the area with the highest dementia mortality had the lowest drinking water $\mathbf{p H}$ [42].

Out of the miscellaneous exposures considered in this section, there seems to be strong evidence that vitamin 
D deficiency is associated with increased risk of dementia and moderate evidence implicating electric and magnetic fields. There is no published evidence supporting any role for weather parameters in dementia risk.

\section{Discussion}

\section{Main findings}

In summary, we found moderate evidence for air pollution exposures being related to dementia risk, particularly nitrogen oxides, particulate matter, and ozone. There was little evidence that toxic heavy metals, or indeed most metals, influence dementia risk, apart from aluminium - where larger, better quality studies suggested an association. Other than silicon, there was little evidence for other trace elements affecting dementia risk, though selenium remains an interesting element. Of the occupational exposures, there was little strong evidence, but the evidence suggests that exposure to some pesticides and, possibly, metals may affect dementia risk. Finally, there was strong evidence for vitamin $\mathrm{D}$ deficiency being associated with raised dementia risk and moderate evidence for electromagnetic fields, though this complicated exposure requires some unpicking.

\section{Limitations of the review and risk of bias within and across studies}

The broad search and systematic methodology of this review is likely to have identified all the available literature. Our exclusion of studies without dementia as their outcome resulted in the exclusion of high quality studies examining the association between environmental risk factors and, for example, cognition or brain structure $[80,81]$. Such studies may shed some light on the pathogenesis of dementia since cognitive or brain changes are important features of dementia but they are not specific to this syndrome. We excluded papers measuring levels of a particular substance (often trace elements) in brain areas or in serum since these physiological changes could not be directly linked to environmental exposure. Our other exclusion criteria (case studies, animal or nutritional studies) are unlikely to have resulted in the exclusion of relevant papers or introduced bias. As mentioned above, we did exclude papers examining the effect of rurality or urbanicity since we have previously reviewed this literature and found in a meta-analysis an increased risk of dementia (particularly Alzheimer's dementia) in rural areas, particularly living in rural areas early in life [16]. One unavoidable bias is that, despite the projected increase in dementia rates occurring disproportionately in low-to-middle income countries [4], the majority of the research was conducted in high-income countries.

One of the major challenges in trying to synthesise such a broad selection of papers is the diversity of methodologies used. When considering Bradford Hill's criteria for inferring a causal association (strength, consistency, specificity, temporality, biological gradient, plausibility, and coherence), one clearly cannot satisfy the temporality criterion with a cross-sectional study, and thus a longitudinal study will provide more robust evidence for the role of a risk factor in the pathogenesis of dementia [82]. Since many of the included studies are cross-sectional, it is often not possible to infer a causal relationship. However, attrition in longitudinal studies can be non-random which can introduce selection bias [83]. Furthermore, no study measured exposures at more than one time point (though some measured the average exposure in a period), which will give a more accurate picture of true exposure over time and is essential in order to test whether there are critical or sensitive periods within the life course [84].

The fact that a number of exposures were only studied in a single study (see Table 2) also weakens support for them as it is impossible to examine the consistency of the association in multiple studies. However, exposures which were investigated in more than one study were also measured in a variety of ways, sometimes with variable quality. For example, many exposures were inferred from an address. This may be reasonable when it is not possible to measure an individual's exposure directly, but the timing of measurement of the exposure is crucial, as will be discussed below. One strength of this approach is that it allows cumulative exposure to be estimated, given the participant's residential history. A more robust measure of an individual's exposure is direct measurement. This will clearly make a study more costly and will also not solve the problem of the timing of the exposure. Less robust, but frequently used for occupational exposures, in particular, is self-report. This does avoid the problem of temporality as different points in the life course can be covered, but will be limited in detail and prone to recall bias [85]. Finally, direct measurement of levels of a substance in the brain is likely to be the most accurate, but is also the most difficult to link to dementia risk - particularly for substances present in health - and thus these studies were excluded from the presence of the review. Alzheimer's disease in the brain and the overt clinical symptoms of Alzheimer's dementia are parallel, related phenomena [9] and the fact that approximately a third of people dying without dementia can have moderate or severe Alzheimer's disease in their brains further complicates the interpretation of autopsy studies [86]. Returning to Bradford Hill's criteria, a number of included studies grouped their exposures into multiple categories, allowing the exploration of a biological gradient in any association observed - for example nitrogen oxides [27] - which can strengthen any inference of a causal relationship.

Where possible, we reported the most-adjusted model in a particular study. Most studies adjusted for age and 
sex and some for other relevant known risk factors for dementia such as educational attainment or comorbidity but adjustment beyond that was highly variable. The possibility of residual confounding still remains.

There was a similar diversity of methodologies (and diagnostic criteria) used to identify people with dementia and it is important to consider whether any of these may introduce bias. Most robust is direct clinical assessment of individuals (often combined with a preliminary screening phase to minimise costs), either specifically for a research project or sourced from medical records. Two-phase screening seems to provide an accurate measure of dementia [87], but screening non-participation may introduce selection bias [88]. A substantial number of studies used dementia mortality as their outcome. This has previously been criticised [89], but more recent studies suggest that dementia reporting is improving, for example $72 \%$ of a memory clinic cohort had dementia correctly diagnosed on their death certificates [90]. Importantly, death certification of dementia did not seem to be related to premorbid intelligence or area-level deprivation in that study (unpublished results available from the author on request). Another study using multiple sources from electronic health records to identify cases of dementia found that death certificates alone identified $83 \%$ of the total number of cases identified by any source [17]. An additional important point is the adequacy of controls in case-control studies - there was some variability in the extent of matching with people with dementia.

Since we know that dementia is a condition which is affected by risk and protective factors throughout the life course [1], when the exposure is measured is crucial. Within life course epidemiology, there are three models of the association between a risk factor and an outcome: accumulation of risk, sensitive periods, and critical periods [91, 92]. Sensitive periods refer to a period of the life course when an exposure has a greater effect than other times. A critical period is the only time when a particular exposure has its effect; it does not affect risk if encountered at a different point in life. Crucially for dementia - which is now indisputably considered a condition of the life course [93] - the exposure in a study must be measured sufficiently early in life plausibly to be involved in the pathogenesis of a condition which begins years or even decades before the clinical onset of symptoms [94]. For example, we have found evidence above for an association between air pollution and dementia but it is not clear at what stage of life exposure is important. A recent study found a biomarker which has been proposed for Alzheimer's disease (reduced cerebrospinal fluid levels of $A \beta_{1-42}$ [95]) in children in Mexico City who had been exposed to high levels of air pollution in utero and throughout their life compared to controls [96]. The issue of timing of exposures has been rather neglected by the published literature on potential environmental risk factors for dementia and should be considered in much richer detail in the future.

\section{Comparison with previous literature}

To the best of our knowledge, this is the first comprehensive systematic review of environmental risk factors for dementia. A review article was recently published on environmental risk factors for Parkinson's disease and Alzheimer's disease [20]. However, this article did not take the systematic approach or focus on dementia of the present review - the author included an extremely broad range of risk factors, including some environmental risk factors alongside clinical, lifestyle, and dietary factors. The findings of that review generally agreed with ours and it concluded that there was robust evidence for an increased risk of Alzheimer's disease in relation to exposure to pesticides and that there was weak evidence for an increased risk in relation to levels of aluminium in drinking water and electromagnetic fields.

An older review summarised the literature relating to a number of risk and protective factors and concluded that there was evidence that occupational exposure to solvents, pesticides, and electromagnetic fields as well high levels of aluminium in drinking water were hazardous [21]. A brief review article from around the same time considered young-onset Alzheimer's dementia and highlighted a number of deficiencies in the literature, many of which remain, which frequently consisted of small studies with limited measurements of environmental data, particularly in relation to the life course and what would now be referred to as the 'preclinical' period [97].

\section{Implications}

As mentioned above, if a modifiable environmental risk factor for dementia could be identified and modified, the implications for public health, the economic cost of dementia, and individuals' suffering could be profound. We have reported, albeit with many caveats, a short list of environmental factors which may be related to dementia risk - air pollution (all types); aluminium; silicon; selenium; pesticides; vitamin D; and electric and magnetic fields and it is reasonable to speculate about possible mechanisms which might underlie these associations, if they were to prove causal. These mechanisms could be examined in more detail using methodologies such as Mendelian randomization [98].

Air pollution has been shown to be associated with reduced cerebral blood flow [99] and seems to be neurotoxic [100]. As shown above, brain changes - including cognitive changes and biomarkers - can be identified in children living in areas with high levels of air pollution compared to controls [96]. Aluminium has been found in amyloid plaques and neurofibrillary tangles (pathological 
features of Alzheimer's disease) and, in rat models, aluminium intake increases amyloid expression [101, 102]. Furthermore, it has been suggested that relatively small amounts of aluminium could be neurotoxic and levels could accumulate selectively in certain brain tissues [103]. Silica may reduce absorption or increase excretion of aluminium [39]. Copper could be implicated in the pathogenesis of Alzheimer's disease in a number of ways, including promoting $\mathrm{A} \beta$ aggregation and hyperphosphorylation and aggregation of tau [104]. The role of selenium in human physiology is complex [105] and it is involved in multiple molecular pathways relevant to the development of Alzheimer's disease [23]. Pesticides form a heterogeneous group but some seem to be neurotoxic. Organophosphates, for example, may disrupt cholinergic neurotransmission through inhibition of acetylcholinesterase [69]. Chronic exposure to some pesticides has been linked to multiple neurological conditions, though specific mechanisms remain unclear. Vitamin D has numerous effects relevant to the pathogenesis of Alzheimer's disease, including stimulating macrophages to clear amyloid plaques, reducing amyloid-induced cytotoxicity, as well as maintenance of cerebrovascular function [78]. Electric and magnetic fields have been proposed to affect the brain in a variety of mechanisms - including oxidative stress, apoptosis and necrosis of neurons, and even cytogenetic effects - but no firm mechanistic link with dementia has been made $[73,106]$. It can be seen that several of these putative risk factors could act through multiple routes and it may become even more difficult to disentangle the relative importance of Alzheimer's disease pathology and cerebrovascular disease in causing clinical dementia.

\section{Conclusions}

In conclusion, the published evidence concerning specific environmental risk factors for dementia is generally not strong. However, there seems to be little role for most metals or other trace elements, occupational exposure to lead, inks/dyes, paints/stains/varnishes, gasoline/fuels/oils, liquid plastics/rubbers, vibratory tools, or climate in determining dementia risk. There is at least moderate evidence consistently supporting air pollution, aluminium, silicon, selenium, pesticides, vitamin D, and electromagnetic fields as putative environmental risk factors for dementia. More and better research is needed and we suggest that this shortlist should form the initial focus of attention.

\section{Appendix 1}

Search syntax for PubMed and Web of Science

Alzheimer's OR dementia AND

1. air pollution (air pollut*)

2. climate

3. UV radiation
4. green space

5. industrial pollution (indust* pollut*)

6. drinking water

7. noise pollution

8. low-frequency radiation

9. radiofrequency radiation

10.radon

11.nuclear facilities (nuclear facil* OR nuclear power)

12.contamination (contaminat*)

13.trace elements

\section{Acknowledgements}

All authors are members of the Alzheimer Scotland Dementia Research Centre funded by Alzheimer Scotland. LOJK, JMS, and TCR are members of the University of Edinburgh Centre for Cognitive Ageing \& Cognitive Epidemiology, part of the cross council Lifelong Health and Wellbeing Initiative (G0700704/84698). Funding from the Biotechnology and Biological Sciences Research Council, Engineering and Physical Sciences Research Council, Economic and Social Research Council, and Medical Research Council is gratefully acknowledged. TCR is supported by Alzheimer Scotland through the Marjorie MacBeath fellowship.

All researchers are independent of funders who played no role in this study.

Funding

Alzheimer Scotland (charity).

Availability of data and materials

No additional data are available.

Authors' contributions

JMS and TCR conceived the review; LOK, JMS, IJS, and TCR planned the review; LOJK conducted the searches and tabulated the studies; LOJK and TCR screened results; TCR drafted the manuscript; and LOKJ, JMS, IJS, and TCR revised the manuscript. All authors have seen and approved the final, submitted version of this manuscript.

\section{Competing interests}

The authors declare that they have no competing interests.

\section{Consent for publication}

N/A

Ethics approval and consent to participate

N/A

\section{Author details}

'Alzheimer Scotland Dementia Research Centre, University of Edinburgh, Edinburgh, UK. ${ }^{2}$ Centre for Cognitive Ageing \& Cognitive Epidemiology, University of Edinburgh, Edinburgh, UK. ${ }^{3}$ Scottish Dementia Clinical Research Network, NHS Scotland, Perth, UK. ${ }^{4}$ Faculty of Health and Life Sciences, Northumbria University, Newcastle-upon-Tyne, UK. ${ }^{5}$ Centre for Dementia Prevention, University of Edinburgh, Edinburgh, UK. ${ }^{6}$ Division of Psychiatry, Centre for Clinical Brain Sciences, University of Edinburgh, Edinburgh, UK.

Received: 22 March 2016 Accepted: 19 September 2016 Published online: 12 October 2016

\section{References}

1. Whalley $L$, Dick FD, McNeill G. A life-course approach to the aetiology of late-onset dementias. Lancet Neurol. 2006;5(1):87-96.

2. Whalley LJ. Understanding Brain Aging and Dementia: a life course approach. New York: Columbia University Press; 2015.

3. World Health Organization. Dementia: a public health priority. Geneva: World Health Organization; 2012.

4. Prince M, Guerchet M, Prina M. The Global Impact of Dementia 2013-2050. London: Alzheimer's Disease International; 2013. 
5. Prince M, Wimo A, Guerchet M, Ali G-C, Wu Y-T, Prina M. World Alzheimer Report 2015. The Global Impact of Dementia: An analysis of prevalence, incidence, cost and trends. London: Alzheimer's Disease International; 2015.

6. Prince M, Albanese E, Guerchet M, Prina M. World Alzheimer Report 2014. Dementia and Risk Reduction: An analysis of protective and modifiable factors. London: Alzheimer Disease International; 2014.

7. Baumgart M, Snyder HM, Carrillo MC, Fazio S, Kim H, Johns H. Summary of the evidence on modifiable risk factors for cognitive decline and dementia: A population-based perspective. Alzheimers Dement. 2015;11(6):718-26.

8. Xu W, Tan L, Wang HF, Jiang T, Tan MS, Tan L, Zhao QF, Li JQ, Wang J, Yu JT. Meta-analysis of modifiable risk factors for Alzheimer's disease. J Neurol Neurosurg Psychiatry. 2015. doi:10.1136/jnnp-2015-310548

9. Russ TC, Ritchie K, Ritchie CW. Prevention of Alzheimer's Disease and Alzheimer's Dementia. In: Ames D, Burns A, O'Brien JT, editors. Dementia. 5th ed. London: Taylor \& Francis; In press.

10. Brookmeyer R, Gray S, Kawas C. Projections of Alzheimer's disease in the United States and the public health impact of delaying disease onset. Am J Public Health. 1998;88(9):1337-42.

11. Brookmeyer $R$, Johnson $E$, Ziegler-Graham $K$, Arrighi HM. Forecasting the global burden of Alzheimer's disease. Alzheimers Dement. 2007;3(3):186-91.

12. Ritchie CW, Molinuevo JL, Truyen L, Satlin A, Van der Geyten S, Lovestone S. Development of interventions for the secondary prevention of Alzheimer's dementia: the European Prevention of Alzheimer's Dementia (EPAD) project. Lancet Psychiatry. 2016;3(2):179-86.

13. Barnes DE, Yaffe $K$. The projected effect of risk factor reduction on Alzheimer's disease prevalence. Lancet Neurol. 2011;10(9):819-28.

14. Norton S, Matthews FE, Barnes DE, Yaffe K, Brayne C. Potential for primary prevention of Alzheimer's disease: an analysis of population-based data. Lancet Neurol. 2014;13(8):788-94.

15. Ebbert MT, Ridge PG, Wilson AR, Sharp AR, Bailey M, Norton MC, Tschanz JT, Munger RG, Corcoran CD, Kauwe JS. Population-based analysis of Alzheimer's disease risk alleles implicates genetic interactions. Biol Psychiatry. 2014;75(9):732-7

16. Russ TC, Batty GD, Hearnshaw GF, Fenton C, Starr JM. Geographical variation in dementia: systematic review with meta-analysis. Int J Epidemiol. 2012;41(4):1012-32.

17. Russ TC, Gatz M, Pedersen NL, Hannah J, Wyper G, Batty GD, Deary IJ, Starr JM. Geographical variation in dementia: examining the role of environmental factors in Sweden and Scotland. Epidemiology. 2015;26(2):263-70.

18. Whalley LJ. Spatial distribution and secular trends in the epidemiology of Alzheimer's disease. Neuroimaging Clin N Am. 2012;22(1):1-10. vii.

19. Russ TC, Murianni L, Icaza G, Slachevsky A, Starr JM. Geographical Variation in Dementia Mortality in Italy, New Zealand, and Chile: The Impact of Latitude, Vitamin D, and Air Pollution. Dement Geriatr Cogn Disord. 2016;42(1-2):31-41. http://www.ncbi.nlm.nih.gov/pubmed/27536986.

20. Campdelacreu J. Parkinson disease and Alzheimer disease: environmental risk factors. Neurologia (Barcelona, Spain). 2014;29(9):541-9.

21. McDowell I. Alzheimer's disease: insights from epidemiology. Aging Clin Exp Res. 2001;13(3):143-62.

22. Richardson EA, Mitchell RJ, Shortt NK, Pearce J, Dawson TP. Evidence-based selection of environmental factors and datasets for measuring multiple environmental deprivation in epidemiological research. Environ Health. 2009;8 Suppl 1:S18.

23. Loef M, Schrauzer GN, Walach $H$. Selenium and Alzheimer's disease: a systematic review. J Alzheimers Dis. 2011;26(1):81-104.

24. Loef M, Walach H. Copper and iron in Alzheimer's disease: a systematic review and its dietary implications. Br J Nutr. 2012;107(1):7-19.

25. Rondeau V, Commenges D, Jacamin-Gadda H, Dartigues JF. Relation between aluminum concentrations in drinking water and Alzheimer's disease: An 8-year follow-up study. Am J Epidemiol. 2000;152(1):59-66.

26. Moher D, Liberati A, Tetzlaff J, Altman DG: Preferred reporting items for systematic reviews and meta-analyses: the PRISMA statement. BMJ. 2009;339:b2535

27. Oudin A, Forsberg B, Nordin Adolfsson A, Lind N, Modig L, Nordin M, Nordin S, Adolfsson R, Nilsson LG. Traffic-Related Air Pollution and Dementia Incidence in Northern Sweden: A Longitudinal Study. Environ Health Perspect. 2016;124(3):306-312.

28. Chang KH, Chang MY, Muo CH, Wu TN, Chen CY, Kao CH. Increased risk of dementia in patients exposed to nitrogen dioxide and carbon monoxide: a population-based retrospective cohort study. PLoS One. 2014;9(8):e103078.

29. Chen R, Wilson K, Chen Y, Zhang D, Qin X, He M, Hu Z, Ma Y, Copeland JR. Association between environmental tobacco smoke exposure and dementia syndromes. Occup Environ Med. 2013;70(1):63-9.
30. Brayne C, McCracken C, Matthews FE. Cohort profile: the Medical Research Council Cognitive Function and Ageing Study (CFAS). Int J Epidemiol. 2006;35(5):1140-5.

31. Matthews FE, Arthur A, Barnes LE, Bond J, Jagger C, Robinson L, Brayne C. A two-decade comparison of prevalence of dementia in individuals aged 65 years and older from three geographical areas of England: results of the Cognitive Function and Ageing Study I and II. Lancet. 2013;382(9902):1405-12.

32. Lobo A, Saz P, Dia JL. The AGECAT "organic" section as a screening instrument for minor cognitive deficits. Psychiatr J Univ Ott; Revue de psychiatrie de I'Universite d'Ottawa. 1990;15(4):212-5.

33. Jung CR, Lin YT, Hwang BF. Ozone, particulate matter, and newly diagnosed Alzheimer's disease: a population-based cohort study in Taiwan. J Alzheimers Dis. 2015:44(2):573-84.

34. Wu Y-C, Lin Y-C, Yu H-L, Chen J-H, Chen C-D, Chen T-F, Sun Y, Wen L-L, Yip P-K, Chu Y-M. Association between air pollutants and dementia risk in the elderly. Alzheimer's \& Dement. 2015;1(2):220-8.

35. Fox MA. Project Update: Evaluating the Community Health Legacy of WWI Chemical Weapons Testing. J Community Health. 2014;39(5):997-1003.

36. Dani SU. Arsenic for the fool: An exponential connection. Sci Total Environ. 2010;408(8):1842-6.

37. Emard JF, Andre P, Thouez JP, Mathieu J, Boily C, Beaudry M, Cholette A, Robitaille Y, Bouchard R, Daoud N, et al. Geographical distribution of Alzheimer's disease cases at birth and the geochemical profile of Saguenay-Lac-Saint-Jean Quebec, Canada (IMAGE Project). Water Air Soil Pollut. 1994;72(1-4):251-64.

38. Dartigues JF, Gagnon M, Michel P, Letenneur L, Commenges $D$, Barberger-Gateau P, Auriacombe S, Rigal B, Bedry R, Alperovitch A, et al. The Paquid research program on the epidemiology of dementia. Methods and initial results. Rev Neurol. 1991;147(3):225-30.

39. Rondeau V, Jacqmin-Gadda H, Commenges D, Helmer C, Dartigues JF. Aluminum and silica in drinking water and the risk of Alzheimer's disease or cognitive decline: findings from 15-year follow-up of the PAQUID cohort. Am J Epidemiol. 2009;169(4):489-96.

40. Flaten TP. Geographical associations between aluminium in drinking water and death rates with dementia (including Alzheimer's disease), Parkinson's disease and amyotrophic lateral sclerosis in Norway. Environ Geochem Health. 1990;12(1-2):152-67.

41. Forbes WF, Gentleman JF, Maxwell CJ. Concerning the role of aluminum in causing dementia. Exp Gerontol. 1995;30(1):23-32.

42. Frecker MF. Dementia in Newfoundland: identification of a geographical isolate? J Epidemiol Community Health. 1991;45(4):307-11.

43. McLachlan DRC, Bergeron MD, Smith JE, Boomer D, Rifat SL. Risk for neuropathologically confirmed Alzheimer's disease and residual aluminum in municipal drinking water employing weighted residential histories. Neurology. 1996:46(2):401-5.

44. Neri LC, Hewitt D. Aluminium, Alzheimer's disease, and drinking water. Lancet. 1991;338(8763):390.

45. Vogt T. Water quality and health: study of a possible relation between aluminum in drinking water and dementia. (Pamphlet). Central Bureau of Statistics of Norway. 1986;77:1986.

46. Martyn CN, Coggon DN, Inskip H, Lacey RF, Young WF. Aluminum concentrations in drinking water and risk of Alzheimer's disease. Epidemiology. 1997;8(3):281-6.

47. Forster DP, Newens AJ, Kay DW, Edwardson JA. Risk factors in clinically diagnosed presenile dementia of the Alzheimer type: a case-control study in northern England. J Epidemiol Community Health. 1995;49(3):253-8.

48. Taylor GA, Newens AJ, Edwardson JA, Kay DW, Forster DP. Alzheimer's disease and the relationship between silicon and aluminium in water supplies in northern England. J Epidemiol Community Health. 1995;49(3):323-4.

49. Shen $X-L, Y u J-H$, Zhang D-F, Xie J-X, Jiang H. Positive relationship between mortality from Alzheimer's disease and soil metal concentration in mainland China. J Alzheimers Dis. 2014;42(3):893-900.

50. Thompson C, Markesbery W, Ehmann W, Mao Y, Vance D. Regional brain trace-element studies in Alzheimer's disease. Neurotoxicology. 1987;9(1):1-7.

51. Still CN, Kelley P. On the incidence of primary degenerative dementia Vs water fluoride content in South-Carolina. Neurotoxicology. 1980;1(4):125-31.

52. Abner EL, Kryscio RJ, Caban-Holt AM, Schmitt FA. Baseline subjective memory complaints associate with increased risk of incident dementia: the PREADVISE trial. J Prev Alzheimers Dis. 2015;2(1):11-6.

53. Kryscio RJ, Abner EL, Schmitt FA, Goodman PJ, Mendiondo M, Caban-Holt A Dennis BC, Mathews M, Klein EA, Crowley JJ. A randomized controlled 
Alzheimer's disease prevention trial's evolution into an exposure trial: the PREADVISE Trial. J Nutr Health Aging. 2013;17(1):72-5.

54. Kryscio RJ, Mendiondo MS, Schmitt FA, Markesbery WR. Designing a large prevention trial: statistical issues. Stat Med. 2004;23(2):285-96.

55. Engelhart MJ, Ruitenberg A, Swieten JC, Witteman JCM, Hofman A, Breteler MMB. Dietary anti-oxidants and the risk of dementia. The Rotterdam study. Neurobiol Aging. 2000;21:203.

56. Engelhart MJ, Geerlings MI, Ruitenberg A, et al. Dietary intake of antioxidants and risk of Alzheimer disease. JAMA. 2002;287(24):3223-9.

57. Gillette-Guyonnet S, Andrieu S, Nourhashemi F, de La Gueronniere V, Grandjean H, Vellas B. Cognitive impairment and composition of drinking water in women: findings of the EPIDOS Study. Am J Clin Nutr. 2005;81(4):897-902.

58. Graves AB, Rosner D, Echeverria D, Mortimer JA, Larson EB. Occupational exposures to solvents and aluminium and estimated risk of Alzheimer's disease. Occup Environ Med. 1998;55:627-33.

59. Gun RT, Korten AE, Jorm AF, Henderson AS, Broe GA, Creasey H, McCusker E, Mylvaganam A. Occupational risk factors for Alzheimer disease: a case-control study. Alzheimer Dis Assoc Disord. 1997;11(1):21-7.

60. Peters S, Reid A, Fritschi L, de Klerk N, Musk AW. Long-term effects of aluminium dust inhalation. Occup Environ Med. 2013;70(12):864-8.

61. Salib E, Hillier V. A case-control study of Alzheimer's disease and aluminium occupation. Br J Psychiatry. 1996;168:244-9.

62. Tyas SL, Manfreda J, Strain LA, Montgomery PR. Risk factors for Alzheimer's disease: a population-based, longitudinal study in Manitoba, Canada. Int J Epidemiol. 2001;30(3):590-7.

63. Koeman T, Schouten LJ, van den Brandt PA, Slottje P, Huss A, Peters S, Kromhout $H$, Vermeulen R. Occupational exposures and risk of dementiarelated mortality in the prospective Netherlands Cohort Study. Am J Ind Med. 2015;58(6):625-35.

64. Gauthier E, Fortier I, Courchesne F, Pepin P, Mortimer J, Gauvreau D. Environmental pesticide exposure as a risk factor for Alzheimer's disease: A case-control study. Environ Res. 2001;86(1):37-45.

65. Hayden KM, Norton MC, Darcey D, Ostbye T, Zandi PP, Breitner JC, Welsh-Bohmer KA. Occupational exposure to pesticides increases the risk of incident AD: the Cache County study. Neurology. 2010;74(19):1524-30.

66. McDowell I, Hill G, Lindsay J, Helliwell B, Costa L, Beattie L, Hertzman C, Tuokko H, Gutman G, Parhad I, et al. The Canadian study of health and aging —risk factors for Alzheimer's disease in Canada. Neurology. 1994;44(11):2073-80.

67. Povey AC, McNamee R, Alhamwi H, Stocks SJ, Watkins G, Burns A, Agius R. Pesticide exposure and screen-positive neuropsychiatric disease in British sheep farmers. Environ Res. 2014;135:262-70.

68. Santibanez M, Bolumar F, Garcia AM. Occupational risk factors in Alzheimer's disease: a review assessing the quality of published epidemiological studies. Occup Environ Med. 2007;64(11):723-32.

69. Zaganas I, Kapetanaki S, Mastorodemos V, Kanavouras K, Colosio C, Wilks MF, Tsatsakis AM. Linking pesticide exposure and dementia: what is the evidence? Toxicology. 2013;307:3-11.

70. Baldi I. Neurodegenerative diseases and exposure to pesticides in the elderly. Am J Epidemiol. 2003;157(5):409-14.

71. Kukull WA, Larson EB, Bowen JD, McCormick WC, Teri U, Pfanschmidt ML, Thompson JD, O'Meara ES, Brenner DE, Belle G. Solvent exposure as a risk factor for Alzheimer's disease: a case-control study. Am J Epidemiol. 1995;141(11):1059-71.

72. Salib E, Sharp N. Does the weather influence dementia admissions? Int J Geriatr Psychiatry. 1999;14(11):925-35.

73. Garcia AM, Sisternas A, Hoyos SP. Occupational exposure to extremely low frequency electric and magnetic fields and Alzheimer disease: a meta-analysis. Int J Epidemiol. 2008;37(2):329-40

74. Huss A, Spoerri A, Egger M, Roosli M. Residence near power lines and mortality from neurodegenerative diseases: longitudinal study of the Swiss population. Am J Epidemiol. 2009;169(2):167-75.

75. Schuez J, Waldemar G, Olsen JH, Johansen C. Risks for central nervous system diseases among mobile phone subscribers: a Danish retrospective cohort study. PLoS One. 2009;4(2):e4389.

76. Afzal S, Bojesen SE, Nordestgaard BG. Reduced 25-hydroxyvitamin D and risk of Alzheimer's disease and vascular dementia. Alzheimers Dement. 2014;10(3):296-302.

77. Annweiler C, Rolland Y, Schott AM, Blain H, Vellas B, Beauchet O. Serum vitamin $D$ deficiency as a predictor of incident non-Alzheimer dementias: a 7-year longitudinal study. Dement Geriatr Cogn Disord. 2011;32(4):273-8.

78. Littlejohns TJ, Henley WE, Lang IA, Annweiler C, Beauchet O, Chaves PH, Fried L, Kestenbaum BR, Kuller LH, Langa KM, et al. Vitamin D and the risk of dementia and Alzheimer disease. Neurology. 2014;83(10):920-8.

79. Wilkins CH, Sheline YI, Roe CM, Birge SJ, Morris JC. Vitamin D deficiency is associated with low mood and worse cognitive performance in older adults. Am J Geriatr Psychiatry. 2006;14(12):1032-40.

80. Chen JC, Wang X, Wellenius GA, Serre ML, Driscoll I, Casanova R, MCArdle JJ, Manson JE, Chui HC, Espeland MA. Ambient air pollution and neurotoxicity on brain structure: Evidence from women's health initiative memory study. Ann Neurol. 2015;78(3):466-76.

81. Llewellyn DJ, Lang IA, Langa KM, Naughton F, Matthews FE. Exposure to secondhand smoke and cognitive impairment in non-smokers: national cross sectional study with cotinine measurement. BMJ (Clinical research ed). 2009;338:b462.

82. Bradford Hill A. The environment and disease: association or causation? Proc R Soc Med. 1965;58(5):295-300.

83. Vega S, Benito-León J, Bermejo-Pareja F, Medrano MJ, Vega-Valderrama LM, Rodríguez C, Louis ED. Several factors influenced attrition in a populationbased elderly cohort: Neurological disorders in Central Spain Study. J Clin Epidemiol. 2010;63(2):215-22.

84. Lynch J, Smith GD. A life course approach to chronic disease epidemiology. Annu Rev Public Health. 2005;26:1-35.

85. Batty GD, Lawlor DA, Macintyre S, Clark H, Leon DA. Accuracy of adults' recall of childhood social class: findings from the Aberdeen children of the 1950s study. J Epidemiol Community Health. 2005;59(10):898-903.

86. Bennett D, Schneider J, Arvanitakis Z, Kelly J, Aggarwal N, Shah R, Wilson R. Neuropathology of older persons without cognitive impairment from two community-based studies. Neurology. 2006;66(12):1837-44

87. Bermejo-Pareja F, Benito-Leon J, Vega S, Olazara J, De Toledo M, Di J, Sa F, Morales-Gonza J, Trincado R, Portera-Sa A. Consistency of clinical diagnosis of dementia in NEDICES: a population-based longitudinal study in Spain. J Geriatr Psychiatry Neurol. 2009;22(4):246-255.

88. Bermejo F, Gabriel R, Vega S, Morales J, Rocca W, Anderson D. Problems and issues with door-to-door, two-phase surveys: an illustration from central Spain. Neuroepidemiology. 2001;20(4):225-31.

89. Martyn CN, Pippard EC. Usefulness of mortality data in determining the geography and time trends of dementia. J Epidemiol Community Health. 1988;42(2):134-7.

90. Russ TC, Batty GD, Starr JM. Cognitive and behavioural predictors of survival in Alzheimer disease: results from a sample of treated patients in a tertiary-referral memory clinic. Int J Geriatr Psychiatry. 2012;27(8):844-53.

91. Ben-Shlomo Y, Kuh D. A life course approach to chronic disease epidemiology: conceptual models, empirical challenges and interdisciplinary perspectives. Int J Epidemiol. 2002;31(2):285-93.

92. Kuh D, Ben-Shlomo Y, Lynch J, Hallqvist J, Power C. Life course epidemiology. J Epidemiol Community Health. 2003;57(10):778.

93. Russ TC, Kivimaki M, Starr JM, Stamatakis E, Batty GD. Height in relation to dementia death: individual participant meta-analysis of 18 UK prospective cohort studies. Br J Psychiatry J Ment Sci. 2014;205(5):348-54.

94. Braak H, Braak E. Frequency of stages of Alzheimer-related lesions in different age categories. Neurobiol Aging. 1997;18(4):351-7.

95. Ritchie C, Smailagic N, Noel-Storr AH, Takwoingi Y, Flicker L, Mason SE, McShane R. Plasma and cerebrospinal fluid amyloid beta for the diagnosis of Alzheimer's disease dementia and other dementias in people with mild cognitive impairment $(\mathrm{MCl})$. Cochrane Database Syst Rev. 2014;6:Cd008782.

96. Calderón-Garcidueñas L, Chao C, Thompson C, Rodríguez-Díaz J, Franco-Lira M CSF biomarkers: Low amyloid- $\beta 1-42$ and BDNF and high IFN $\gamma$ differentiate children exposed to Mexico city high air pollution $V$ controls. J Alzheimers Dis Parkinsonism. 2015;5(189):2161. 0460.1000189.

97. Whalley LJ. Early-onset Alzheimer's disease in Scotland: environmental and familial factors. Br J Psychiatry. 2001;178(40):553-9.

98. Lawlor DA, Harbord RM, Sterne JA, Timpson N, Davey Smith G. Mendelian randomization: using genes as instruments for making causal inferences in epidemiology. Stat Med. 2008:27(8):1133-63.

99. Wellenius GA, Boyle LD, Wilker EH, Sorond FA, Coull BA, Koutrakis P, Mittleman MA, Lipsitz LA. Ambient fine particulate matter alters cerebral hemodynamics in the elderly. Stroke. 2013;44(6):1532-6. 
100. Block ML, Elder A, Auten RL, Bilbo SD, Chen H, Chen J-C, Cory-Slechta DA, Costa D, Diaz-Sanchez D, Dorman DC. The outdoor air pollution and brain health workshop. Neurotoxicology. 2012;33(5):972-84.

101. Edwardson JA, Candy JM, Ince PG, MCArthur FKM, Morris CM, Oakley AE, Taylor GA, Bjertness E. Aluminium accumulation, b-amyloid deposition and neurofibrillary changes in the central nervous system, Aluminium in biology and medicine. Chichester: Wiley; 1992. p. 165-85.

102. El-Rahman SSA. Neuropathology of aluminum toxicity in rats (glutamate and GABA impairment). Pharmacol Res. 2003;47(3):189-94.

103. Tomljenovic L. Aluminum and Alzheimer's disease: after a century of controversy, is there a plausible link? J Alzheimers Dis. 2011;23(4):567-98.

104. Hung YH, Bush Al, Cherny RA. Copper in the brain and Alzheimer's disease. JBIC J Biol Inorg Chem. 2010;15(1):61-76.

105. Rayman MP. Selenium and human health. Lancet. 2012;379(9822):1256-68.

106. Maes A, Verschaeve L. Can cytogenetics explain the possible association between exposure to extreme low-frequency magnetic fields and Alzheimer's disease? J Appl Toxicol. 2012;32(2):81-7.

107. Gauthier E, Fortier I, Courchesne F, Pepin P, Mortimer J, Gauvreau D. Aluminum forms in drinking water and risk of Alzheimer's disease. Environ Res. 2000;84(3):234-46.

108. Wettstein A, Aeppli J, Gautschi K, Peters M. Failure to find a relationship between mnestic skills of octogenarians and aluminum in drinking water. Int Arch Occup Environ Health. 1991;63(2):97-103.

109. Civita M, Fiorucci A, Mie R. Identification of anomalous aluminium contents in surface and ground water in the Alba territory (NW Italy). Geostand Newslett-the Journal of Geostandards and Geoanalysis. 2001;25(2-3):431-9.

110. Dartigues J-F, Gagnon M, Barberger-Gateau P, Letenneur L, Commenges D, Sauvel C, Michel P, Salamon R. The Paquid epidemiological program on brain ageing. Neuroepidemiology. 1992;11 Suppl 1:14-8.

111. Vergara X, Kheifets L, Greenland S, Oksuzyan S, Cho YS, Mezei G. Occupational exposure to extremely low-frequency magnetic fields and neurodegenerative disease: a meta-analysis. J Occup Environ Med. 2013:55(2):135-46.

\section{Submit your next manuscript to BioMed Central and we will help you at every step:}

- We accept pre-submission inquiries

- Our selector tool helps you to find the most relevant journal

- We provide round the clock customer support

- Convenient online submission

- Thorough peer review

- Inclusion in PubMed and all major indexing services

- Maximum visibility for your research

Submit your manuscript at www.biomedcentral.com/submit

) Biomed Central 